\title{
Physical and isotopic characteristics in peri-urban landscapes: a case study at the lower Volta River Basin, Ghana
}

\author{
E. K. Gampson ${ }^{1}$ V. K. Nartey ${ }^{2}$ A. A. Golow ${ }^{3}$ T. T. Akiti ${ }^{3}$ - M. A. Sarfo ${ }^{1}$ \\ M. Salifu ${ }^{1} \cdot$ F. Aidoo $^{1} \cdot$ A. R. Fuseini ${ }^{1}$
}

Received: 19 September 2014 / Accepted: 19 April 2015/Published online: 14 May 2015

(c) The Author(s) 2015. This article is published with open access at Springerlink.com

\begin{abstract}
The study presents the application of selected multivariate techniques: display methods (principal component analysis) and unsupervised pattern recognition (cluster analysis) in an attempt to discriminate sources of variation of water quality. PCA has allowed the identification of a reduced number of latent factors with a hydrochemical meaning: natural and anthropogenic (domestic and agricultural activities) factors, which also agrees with the R-mode hierarchical cluster analysis (HCA). Q-mode HCA also corroborates the results of the correlation analysis in relation to sampling sites established on hydrochemical parameters, indicating that there are no spatial and temporal characteristics among the sampling sites in the study area. The suitability of river water for irrigation use was assessed in the study area. A plot of the sodium adsorption ratio (SAR) and salinity data on a semilog axis suggests that river water provides good irrigation quality in the area. According to the SAR values plotted in the USSL Staff diagram, $100 \%$ of the river water samples fall in C1S1 (low salinity-low sodium type) group, which provides good irrigation quality to river water from this area. Also, all the data points showed permeability index values in Class II category which is suitable for irrigation purposes. Recorded magnesium ratio and Kelly's ratio showed that $<50 \%$ of the river water samples were suitable for
\end{abstract}

\section{E. K. Gampson}

e.gampson@gaecgh.org

1 Ghana Atomic Energy Commission, Kwabenya, P. O. Box LG 80, Legon-Accra, Ghana

2 Department of Chemistry, University of Ghana, P. O. Box LG 56, Legon-Accra, Ghana

3 Graduate School of Nuclear and Allied Sciences, University of Ghana, P. O. Box LG 80, Accra, Ghana irrigation purposes. Stable isotope data of water $\left(\delta^{18} \mathrm{O}\right.$ and $\delta^{2} \mathrm{H}$ ) obtained revealed that stream waters joining the Volta River were depleted and possibly recharged by rain and waters from the Akwapim Mountains (located at the western part of the Volta River) than the isotopically heavy evaporated waters found within the Lower Volta River. These results would therefore be useful for water balance studies in the study area.

Keywords Stable isotope - Principal component analysis · Hierarchical cluster analysis - Manya Krobo . Tongu · Lower Volta River Basin · Hydrochemical

\section{Introduction}

River basins generally constitute areas with a high population density owing to favorable living conditions such as the availability of fertile lands; water for irrigation, industrial or drinking purposes; and efficient means of transportation. Rivers play a major role in assimilating or carrying industrial and municipal wastewater, manure discharges and runoff from agricultural fields, roadways and streets, which are responsible for river pollution (Stroomberg et al. 1995; Ward and Elliot 1995). Rivers too constitute the main water resources in inland areas for drinking, irrigation and industrial purposes; thus, it is a prerequisite for effective and efficient water management to have reliable information of water quality. The discharge of industrial and municipal wastewater and manure can be considered a constant polluting source, but not of the surface runoff which is seasonal and highly affected by climate. Flow in rivers is a function of many factors including precipitation, surface runoff, interflow, groundwater flow and pumped inflow and outflow. Seasonal variations of 
these factors have a strong effect on flow rates and hence on the concentration of pollutants in the river water (Vega et al. 1998). Also, organic matter decay can contribute phosphates, bicarbonate, nitrate and dissolved solids to the chemistry of surface waters. Organic matter decomposition also has the tendency to reduce the dissolved oxygen content of natural water. Factors such as the residence time of water, the temperature and the presence of other ions play important roles in determining how much organic matter decays. Anthropogenic forces have the immense tendency to accelerate natural processes that affect water quality. Mineral leaching and the uncontrolled use of toxics in industry can adversely affect the suitability of surface water resources for many purposes.

In Ghana, rural communities and small towns constitute about 12.6 million $(60 \%)$ of the total population (CWSA 2005). Safe drinking water supplies in small towns and rural communities has improved considerably within the last 6 years from about $41 \%$ in 2001 to $52 \%$ in 2005 (CWSA 2005). Yet, the remaining $48 \%$, mainly in rural communities, continue to face major shortage in the supply of good quality water. The deterioration of quality water sources for Manya Krobo and Tongu District rural communities in the study area could be partly attributed to the construction of two dams built on the Volta River at Akosombo and Akuse in the 1960s and 1970s, respectively. This caused considerable changes in the water balance of the Lower Volta Basin. The alternate flooding of ponds and creeks that occurred prior to the construction of the dams ceased (Whyte 1981) resulting in the permanent drying up of some sources of drinking water within the basin. Furthermore, those ponds that did not dry up became infested with snails-harboring weeds (LVEIS 1999).

The surface and groundwater used for domestic and irrigation purposes can vary greatly in quality, depending upon type and quantity of dissolved salts. It contains a wide variety of dissolved inorganic chemical constituents in various concentrations, resulting from chemical and biochemical interactions between water and geological materials. Dissolved salts should be present in irrigation water in relatively small, but significant amounts. They originate from dissolution or weathering of the rocks and soil, including dissolution of lime, gypsum and other slowly dissolved soil minerals. Various irrigation schemes exist under the Ghana Irrigation Development Authority in the study area (Manya Krobo and Tongu districts), but most farmers prefer the private/communal small holder and commercial systems which use the untreated river water for various activities due to inadequate and deteriorated facilities at the various schemes (Miyoshi and Nagayo 2006).

Integrating isotope hydrology in assessing surface water and groundwater resources has proven to yield good results all over the world. Various studies on isotopic application in West Africa, in particular, include Edmunds and Wright (1979), Sonntag et al. (1979), Edmunds and Walton (1980), Fontes et al. (1986), Gasse et al. (1987) and many others. A pioneering work in Ghana on heavy isotope hydrology is attributed to Akiti. Akiti (1977 and 1980) pioneered the use of isotope techniques in the analysis of surface and groundwater in the Accra Plains, Keta Basin and upper regions of Ghana. Akiti in 1980 made an attempt to find out the relationship between the Volta River, some streams and groundwater from the Manya Krobo and Tongu districts using isotope techniques. However, Akiti (1980) did not find any signs of mixing of river water, stream water and groundwater, because streams along the lower Volta River were not sampled. Akiti (1987) also applied environmental isotopes such as ${ }^{2} \mathrm{H}$ (deuterium), ${ }^{18} \mathrm{O}$ (oxygen-18), ${ }^{3} \mathrm{H}$ (tritium) and ${ }^{14} \mathrm{C}$ (carbon-14) to study groundwater in the foothills of the Accra Plains. Pelig-Ba et al. (1990) used ${ }^{2} \mathrm{H}$ and ${ }^{18} \mathrm{O}$ for waters in the Upper East and Upper West regions and the Accra Plains, while Kortatsi and Sekpey (1994) did a similar study using the same stable isotopes for groundwaters in the two upper regions of Ghana. Isotope fractionation is a geochemical tool used to identify surface water and groundwater origin, determine ${ }^{13} \mathrm{C}$ in ${ }^{14} \mathrm{C}$ age determination, residence time and how it is affected by geo-hydrologic and meteorological factors. It can also be used to determine the origin and source of contaminants emanating from agricultural activities or other point sources. Factors such as altitude, evaporation, condensation, evapotranspiration, melting, freezing, chemical and biological processes (Faure and Mensing 2005) are the results of heavy isotope fractionation. Evaporation tends to increase the heavy isotopes in the remaining fraction of liquid as compared to the initial contents. These effects occur for both ${ }^{18} \mathrm{O}$ and ${ }^{2} \mathrm{H}$. In natural waters, their contents are correlated. Using the classical $\delta$-notation, one has for precipitation, $\delta{ }^{2} \mathrm{H}=8 \delta^{18} \mathrm{O}+d$, where 'd' lies in the range 0 to +20 with the most common value for oceanic rains at +10 (Craig 1961). For evaporated waters, there is still a linear correlation at any time of the process: $\delta$ ${ }^{2} \mathrm{H}=a \delta{ }^{18} \mathrm{O}+b$, in which 'a' depends on the local climatic conditions of evaporation and lies generally within the range 3-5, and ' $b$ ' depends on ' $a$ ' and on the initial isotopic content of the water which supplies the evaporitic system.

The stable isotope of water is represented by the $\delta$ notation:

$\delta \%_{\mathrm{o}}=\frac{[R \text { sample }-R \text { standard }]}{R \text { standard }} \times 1000$,

where $R={ }^{2} \mathrm{H} / \mathrm{H},{ }^{18} \mathrm{O} /{ }^{16} \mathrm{O}$ and oxygen-16 $\left({ }^{16} \mathrm{O}\right)$.

Stable isotopes have been applied to river and lake research for several decades. Isotope hydrology has also been used to study surface water and groundwater interactions. 
In recent times, multivariate methods have been used to study the sources of variation of surface and groundwater chemistry. Factor analysis has been widely used to interpret hydrochemical data. Excellent examples of the application of factor analysis to solve hydrochemical problems are contained in Dalton and Upchurch (1978), Ashley and Lloyd (1978), Usunoff and Guzman-Guzman (1989), BrizKishore and Murali (1992), Grande et al. (1996), Huizar et al. (1998), Ceron et al. (1999), Suk and Lee (1999); Sanchez-Martos et al. (2001); Salifu et al. (2013) and Gampson et al. (2013). Multivariate techniques have been used to resolve the hydrochemical parameters (e.g., Seyhan et al. 1985; Razack and Dazy 1990; Join et al. 1997; Liedholz and Schafmeister 1998; Wang et al. 2001; Locsey and Cox 2003), identify geochemical controls on the composition (Adams et al. 2001; Alberto et al. 2001) and separate anomalies such as anthropogenic impacts from the background (Hernandez et al. 1991; Birke and Rauch 1993; Helena et al. 2000; Pereira et al. 2003). Factor analysis, as a multivariate statistical tool, reduces a large data set into a set of variables that represent the hydrochemistry without giving up much of the original information. Hierarchical cluster analysis, HCA, as a multivariate statistical tool has also been widely used to formulate hydrochemical models on the basis of available data (Meng and Maynard 2001).

This paper applies cluster and factor analysis to assess the main controls on the chemistry of the river water from the study area, suitability of the water for irrigation and to establish the relationship between some tributaries and the Volta River using isotope technique.

\section{Background}

The Volta Basin is located in West Africa and lies within latitudes $5^{\circ} 30^{\prime} \mathrm{N}$ and $14^{\circ} 30^{\prime} \mathrm{N}$ and longitudes $2^{\circ} 00^{\prime} \mathrm{E}$ and $5^{\circ} 30^{\prime} \mathrm{W}$ as shown in Fig. 1 (ZEF 2008). The Volta River collects the water of a large territory in West Africa and has broken through the hard quartzite, sandstone and other hard rocks of the Togo structural unit by a narrow, deep and steep gorge.

The basin lies mainly in Ghana (40\%) and Burkina Faso (43\%) with minor parts in Togo (6\%), Cote d'Ivoire (3\%), Mali (4\%) and Benin (4\%). Ghana occupies the downstream part of the basin (Moniod et al. 1977) and is made up of the black, white and lower basins. The study area is located within the Lower Volta Basin and between the Manya Krobo $\left(6^{\circ} 05^{\prime} 50^{\prime \prime} \mathrm{N}, 0^{\circ} 10^{\prime} 10^{\prime \prime} \mathrm{E}\right)$ and Tongu $\left(5^{\circ} 59^{\prime} 40^{\prime \prime} \mathrm{N}\right.$, $0^{\circ} 34^{\prime} 50^{\prime \prime} \mathrm{E}$ ) districts (Fig. 2). The study area lies within the semi-equatorial climate belt and is influenced by southwestern monsoon winds twice a year, resulting in a double rainfall regime with a mean annual rainfall ranging between 195 and $1500 \mathrm{~mm}$. The main rainy season occurs between

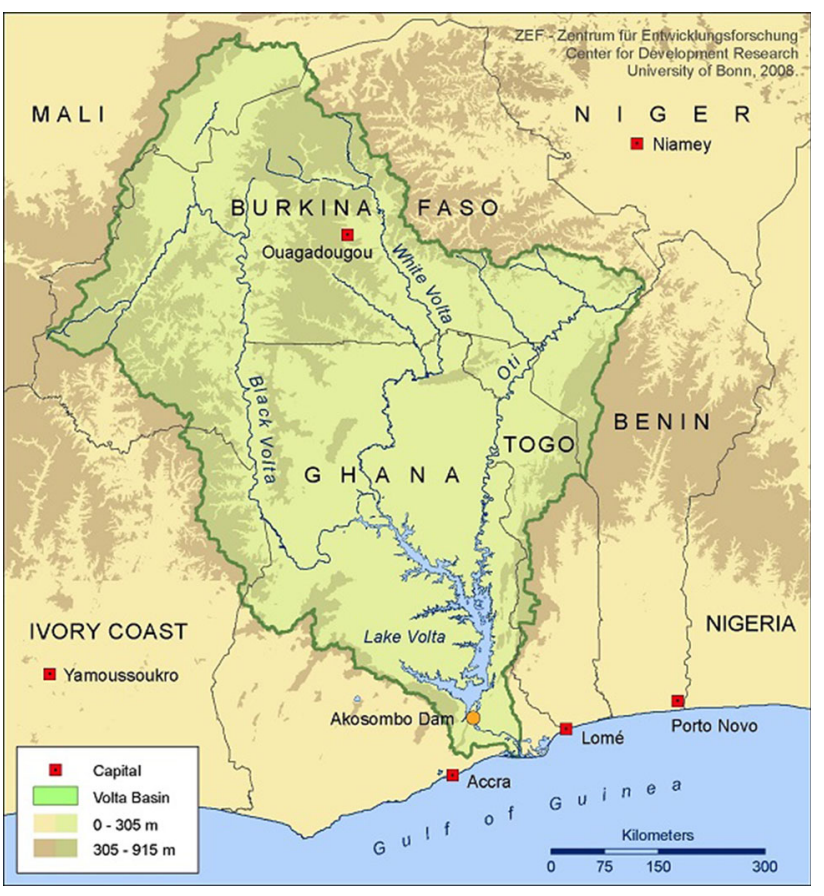

Fig. 1 Map of the Volta River Basin

April and July, while the minor one falls between September and October of every year. The dry and warm season is experienced from November to March. The average relative humidity is high during the wet season, between 70 and $80 \%$, and low in the dry season with about 55 and $60 \%$. The temperature in the study area ranges from 22 to $30^{\circ} \mathrm{C}$ in the wet and dry seasons, respectively. The underlying rocks in the study area are metamorphic in origin and mainly consist of Dahomeyan acid and basic gneisses which are sediments of the Volta Delta and coastal savannah zone. The major soils developed over these geological formations include the Akuse-Bumbi association and these are soils developed from basic gneiss and pyroxenite. The Bumbi series are very poorly drained, very dark gray to black plastic clays occurring within depressing and wide flat valley bottoms. ZiwaiZebe complex, Tondo-Motawme complex and AgawtawPejeglo complex soils are formed over the Dahomeyan acidic gneiss rocks. Toje-Agawtaw association and Amo-Tefle association soils have acidic gneiss and schist as their parent rocks. Ada-Oyibi association, Ada association, AveyimeAda association and Oyibi-Muni association soils have alluvial and coastal deposits as their parent rock (Ministry of Local Government and Rural Development, Ghana, 2010).

\section{Sampling and sample treatment}

Water samples were collected in July 2011 in the wet season and February 2012 in the dry season. Four streams, Canal (S1), Lome (S2), Odzador (S3) and Okue (S4), and 


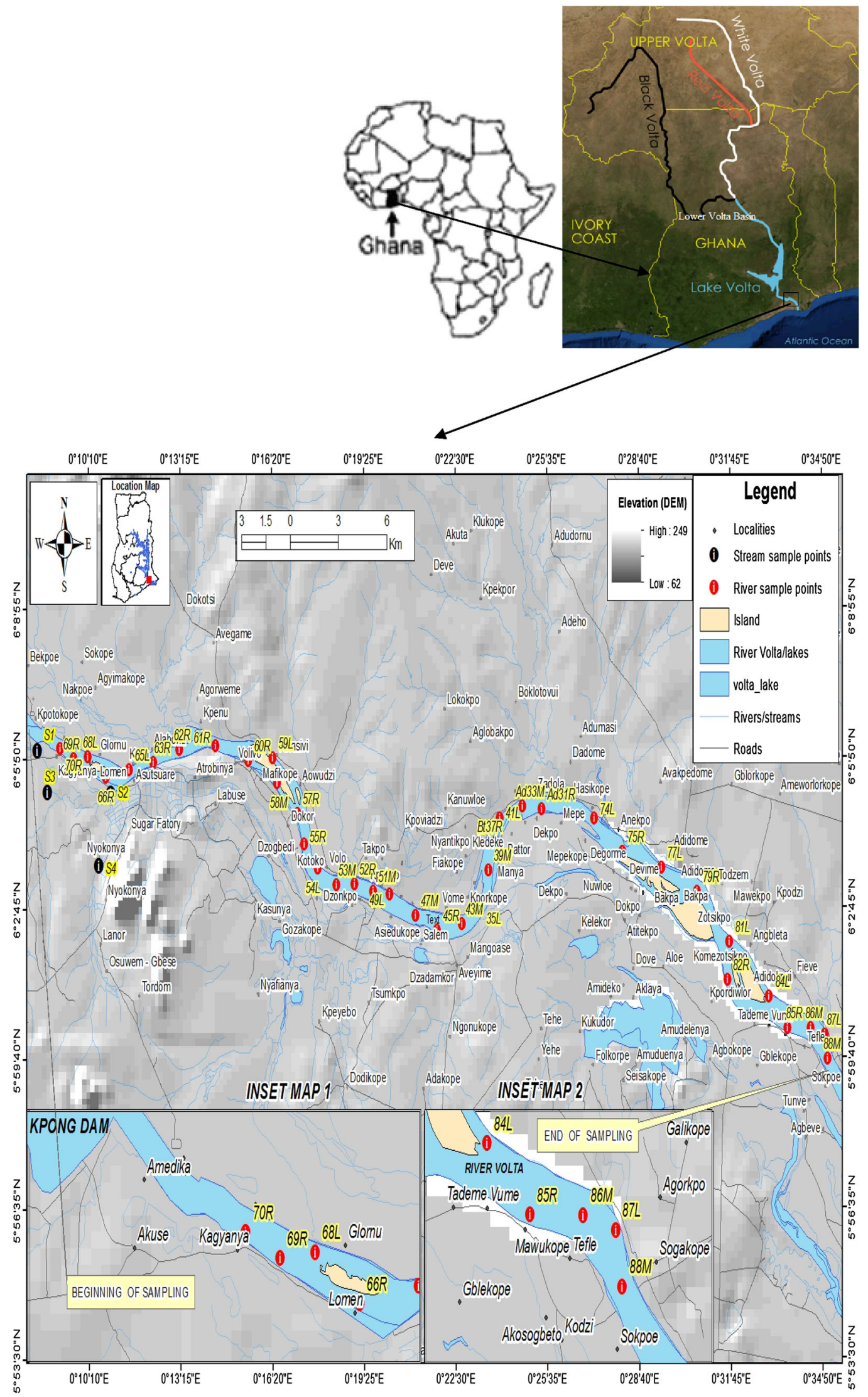

Fig. 2 Map of the study area 
38 surface water samples on different locations on the lower Volta River were analyzed to determine the concentration of various parameters and stable isotopes $\left(\delta^{18} \mathrm{O}\right.$ and $\left.\delta^{2} \mathrm{H}\right)$. Locations of selected sampling sites were determined using the Garmin Vista CP GPS (Fig. 2). The R, $\mathrm{M}$ and $\mathrm{L}$ inserted in the location map represent the right, middle and left portions of the river. The numbers attached to $\mathrm{R}, \mathrm{M}$ and $\mathrm{L}$ are the elevations above mean sea level. $\mathrm{pH}$, temperature, electrical conductivity (EC), salinity, total dissolved solids (TDS) and bicarbonate ion $\left(\mathrm{HCO}_{3}{ }^{-}\right)$were measured in situ. Concentrations of the major cations $\left(\mathrm{Mg}^{2+}, \mathrm{Na}^{+}, \mathrm{K}^{+}, \mathrm{Ca}^{2+}\right)$ were determined in the laboratory after the samples had been treated with acid in the field to discourage bacterial action and oxidation processes. The water samples for anion $\left(\mathrm{NO}_{3}{ }^{-}, \mathrm{PO}_{4}{ }^{3-}, \mathrm{Cl}^{-}\right.$and $\mathrm{SO}_{4}{ }^{2-}$ ) determination were filtered and collected into a $500 \mathrm{ml}$ plastic container. Unfiltered water samples for stable isotope analysis $\left(\delta^{18} \mathrm{O}\right.$ and $\left.\delta^{2} \mathrm{H}\right)$ were collected into $60 \mathrm{~mL}$ glass bottles with poly-sealed lid, not acidified, and any remaining head space was topped off and capped tightly. The $\mathrm{pH}$ and temperature were determined using a (Ecoscan Ion 5) $\mathrm{pH}$ meter. EC, salinity and TDS were determined using a specific conductance meter (HACH SensIon5). $\mathrm{HCO}_{3}{ }^{-}$was determined using $\mathrm{HACH}$, Loveland Co. USA digital titrator. The chloride was determined by the argentometric method, sulfate by the turbidimetry method, phosphate by the vanadate molybdate method and nitrate by UV spectrophotometric method (APHA 1998). Sodium and potassium ions were determined by flame photometry (AWWA 1998).

Irradiations were performed using the Ghana Research Reactor-1 (GHARR-1) facility at Ghana Atomic Energy Commission, Kwabenya. The elements of interest ( $\mathrm{Ca}, \mathrm{Mg}$ ) were assayed using different timing parameters, namely the irradiation time $\left(t_{\mathrm{i}}\right)$, the decay time $\left(t_{\mathrm{d}}\right)$ and the counting time $\left(t_{\mathrm{c}}\right)$. These timing parameters mainly depend on the half-life of the radionuclide produced, that is, short-lived nuclides ( $t_{1 / 2}$ less than a few hours), medium-lived radionuclides ( $t_{1 / 2}$ longer than several hours) and long-lived radionuclides ( $t_{1 / 2}$ longer than several days). Samples and standards were sent into available inner irradiation sites with a thermal flux of $5 \times 10^{11} \mathrm{ncm}^{-2} \mathrm{~s}^{-1}$ when the reactor (GHARR-1) was operated at $15 \mathrm{~kW}$ by means of a pneumatic transfer system (rabbit system) at a pressure of 65 psi. The $t_{\mathrm{i}}, t_{\mathrm{c}}$ and $t_{\mathrm{d}}$ for the water samples were 2,10 and $\leq 3 \mathrm{~min}$, respectively, with respect to $\mathrm{Ca}$ and $\mathrm{Mg}$. Computer-based gamma-ray spectroscopy system of an N-type high-purity germanium (HPGe) detector Model GR2518, an HV power supply model 3105 and a spectroscopy amplifier model 2020, all manufactured by Canberra Industries Inc., an $8 \mathrm{k}$ Silena EMCAplus multichannel analyzer (MCA) emulation software card and a 486 Micro Computer for spectrum data evaluation and analysis were used. The detector operates on a bias voltage of $3000 \mathrm{~V}$ and has resolutions of $0.85 \mathrm{keV}$ (FWHM) and $1.8 \mathrm{keV}$ (FWHM) for ${ }^{57} \mathrm{Co}$ and ${ }^{60} \mathrm{Co}$ gamma-ray energies of 122 and $1332.5 \mathrm{keV}$, respectively. The relative efficiency of the detector was $25 \%$. The qualitative analysis, which involves the identification of $\mathrm{Ca}$ and $\mathrm{Mg}$ elements in the samples, and the quantitative analysis of concentrations were achieved using the gamma-spectrum software of the MAESTRO 32.

Stable isotopes of oxygen and hydrogen were determined using Los Gatos Research DT-100 Liquid-Water Isotope Analyzer (Model 908-008-2000). The water samples for oxygen isotopic analyses were prepared by conventional $\mathrm{H}_{2} \mathrm{O}-\mathrm{CO}_{2}$ equilibration (Epstein and Mayeda 1953) where $5 \mathrm{~mL}$ of each sample was equilibrated with $\mathrm{CO}_{2}$ gas at $25 \pm 0.1{ }^{\circ} \mathrm{C}$ for $24 \mathrm{~h}$. The $\mathrm{CO}_{2}$ gas was then extracted and cryogenically purified in a vacuum line. For deuterium analysis, $\mathrm{Cr}$ at $850{ }^{\circ} \mathrm{C}$ was used to produce hydrogen gas (Coleman et al. 1982). Both $\delta^{18} \mathrm{O}$ and $\delta^{2} \mathrm{H}$ values were determined relative to internal standards that were calibrated using Vienna-Standard Mean Ocean Water (V-SMOW). The data were normalized following Coplen (1988) as follows: $\delta=\left[\left(R_{\mathrm{S}} / R_{\mathrm{V} \text { - }}\right.\right.$ SMow) -1$] \times 1000$, where $R_{\mathrm{S}}$ represents either the ${ }^{18} \mathrm{O} /{ }^{16} \mathrm{O}$ or the ${ }^{2} \mathrm{H} /{ }^{1} \mathrm{H}$ ratio of the sample and $\mathrm{R}_{\mathrm{V} \text {-SMow }}$ is ${ }^{18} \mathrm{O} /{ }^{16} \mathrm{O}$ or the ${ }^{2} \mathrm{H} /{ }^{1} \mathrm{H}$ ratio of the $\mathrm{V}-\mathrm{SMOW}$. The analytical reproducibility was \pm 0.1 and $\pm 1.0 \%$ for the oxygen and deuterium, respectively.

For the statistical analysis, hierarchical cluster analysis (HCA) or squared Euclidean distance scheme was chosen as a similarity/dissimilarity measure among parameters and the linking distances among initial clusters were determined using the Ward's linkage algorithm. Squared Euclidean distances were computed from Eq. (1):

$d_{x y}=\left[\sum_{j=1}^{p}\left(x_{j}-y_{j}\right)\right]$,

where $d_{x y}$ is the squared Euclidean distance between points $x$ and $y$ in $p$-dimensional space and $j$ defines each parameter. A combination of the Euclidean or squared Euclidean distance as a similarity measure and the Ward's agglomeration scheme to link clusters was determined to yield optimal results in HCA. This combination is commonly used in the literature for hydrochemical analysis (e.g., Farnham et al. 2002; Kuells et al. 2000; Güler and Thyne 2004; Helstrup et al. 2007; Yidana et al. 2008). Both Q-mode and R-mode HCA were performed on the hydrochemical parameters. The R-mode HCA was done to classify the parameters into groups based on their similarity with each other, whereas the Q-mode HCA was done to highlight spatial relationships among the sample points. Dendrograms were produced to illustrate the relationships revealed by the HCA. 
In the factor analysis, principal components were used with Kaiser criterion (Kaiser 1960) and varimax rotation. The Kaiser criterion allows only factors that form unique sources of variance in the hydrochemistry to be included in the final factor model. In the Kaiser criterion, factors which represent unique sources of variance in the hydrochemistry are defined as those with an eigenvector sum of at least 1.0. Naturally, it is possible to obtain as many factors as there are variables, but most of these factors cannot be relied upon to correctly interpret the processes taking place from the hydrochemical point of view. Therefore, they are not included in the factor model. Varimax rotation is one of the most commonly used rotation schemes in factor analysis. This is because it maximizes the differences among dissimilar parameters and results in factors, each of which represents a process in the watershed. The factor loadings of each variable in the factor model were used to calculate the factor scores for each location where data were taken. This way, it is possible to explain the impact of each process at each location.

In this study, the SPSS 16.0 for Windows statistical tool was utilized for the description of multivariate analysis to support the conventional hydrochemical techniques. Thirteen hydrochemical variables $(\mathrm{pH}$, Temp, EC, TDS, $\mathrm{HCO}_{3}{ }^{-}, \mathrm{Mg}^{2+}, \mathrm{Na}^{+}, \mathrm{K}^{+}, \mathrm{Cl}^{-}, \mathrm{Ca}^{2+}, \mathrm{NO}_{3}{ }^{-}, \mathrm{SO}_{4}{ }^{2-}$ and $\mathrm{PO}_{4}{ }^{3-}$ ) were used in the statistical analyses. All the data were $\log$ transformed and subsequently standardized to their standard scores (z-cores) as outlined by Brown (1998), so that each variable measured with different units was rescaled to a range of 0-1 to have equal weight for the multivariate statistical analysis.

The sodium adsorption ratio (SAR), magnesium ratio (MR), permeability index (PI) and Kelly's ratio (KR) were also employed to check for the suitability of the river water for irrigation.

To determine the possible source of recharge of the water in the area, the $\delta^{18} \mathrm{O}$ values were plotted against the corresponding $\delta^{2} \mathrm{H}$ values and the line of best fit was compared to the Global Meteoric Water Line (GMWL) as well as the Local Meteoric Water Line (LMWL).

\section{Results and discussion}

Tables 1 and 2 provide a statistical summary of the chemical parameters analyzed for the river water in the study area. It is obvious that the concentrations of most of the parameters are within acceptable ranges for most uses. The lowest $\mathrm{pH}$ of 6.45 at sampling site $65 \mathrm{~L}$ in the wet season could be due to photosynthetic activity and microbial respiration as well as decomposing activities at the site affecting the $\mathrm{pH}$ value.
The salinity of all the water samples was recorded to be $0 \%$. This is an indication that the water is not saline and there is no seawater intrusion. Hence, the salinity was not included in further analysis. The mean values for the parameters for both seasons are presented in the form of standard error bars and gives a general idea of how accurate the measurements are or how far from the reported value the true (error free) value might be (Fig. 3). High levels of $\mathrm{PO}_{4}{ }^{3-}$ have been known to cause digestive

Table 1 Statistical description for the 38 samples analyzed in the wet season

\begin{tabular}{lcclllll}
\hline Parameter & Unit & $N$ & Min. & Max. & Mean & SD & $\begin{array}{l}\text { WHO } \\
(2004) \mathrm{Std}\end{array}$ \\
\hline $\mathrm{pH}$ & & 38 & 6.45 & 7.25 & 6.89 & 0.19 & $6.5-8.5$ \\
Temp & ${ }^{\circ} \mathrm{C}$ & 38 & 26.5 & 30.2 & 28.9 & 0.19 & - \\
$\mathrm{EC}$ & $\mu \mathrm{S} / \mathrm{cm}$ & 38 & 61.7 & 82.2 & 69.76 & 5.23 & 1400 \\
$\mathrm{Salinity}$ & $\%$ o & 0.0 & 0.0 & 0.0 & 0.0 & 0.0 & - \\
$\mathrm{TDS}$ & $\mathrm{mg} / \mathrm{L}$ & 38 & 29.7 & 39.1 & 33.28 & 2.11 & 500 \\
$\mathrm{HCO}_{3}{ }^{-}$ & $\mathrm{mg} / \mathrm{L}$ & 38 & 23.16 & 46.33 & 35.26 & 3.6 & - \\
$\mathrm{Mg}^{2+}$ & $\mathrm{mg} / \mathrm{L}$ & 38 & 2.92 & 23.33 & 9.67 & 3.38 & 50 \\
$\mathrm{Na}^{+}$ & $\mathrm{mg} / \mathrm{L}$ & 38 & 7.8 & 11.0 & 8.53 & 0.61 & 200 \\
$\mathrm{Ca}^{2+}$ & $\mathrm{mg} / \mathrm{L}$ & 38 & 3.2 & 12.8 & 5.55 & 1.85 & 100 \\
$\mathrm{~K}^{+}$ & $\mathrm{mg} / \mathrm{L}$ & 38 & 4.0 & 5.9 & 5.1 & 0.31 & 12 \\
$\mathrm{Cl}^{-}$ & $\mathrm{mg} / \mathrm{L}$ & 38 & 1.99 & 13.99 & 3.99 & 2.46 & 250 \\
$\mathrm{NO}_{3}{ }^{-}$ & $\mathrm{mg} / \mathrm{L}$ & 38 & 1.0 & 24.77 & 11.58 & 8.16 & 50 \\
$\mathrm{SO}_{4}{ }^{2-}$ & $\mathrm{mg} / \mathrm{L}$ & 38 & 6.89 & 28.11 & 16.97 & 6.43 & 250 \\
$\mathrm{PO}_{4}{ }^{3-}$ & $\mathrm{mg} / \mathrm{L}$ & 38 & 1.33 & 10.67 & 4.73 & 2.67 & - \\
\hline
\end{tabular}

$N$ total number of data points, WHO Std World Health Organization standards, $S D$ standard deviation

Table 2 Statistical description for the 38 samples analyzed in the dry season

\begin{tabular}{llllllll}
\hline Parameter & Unit & $N$ & Min. & Max. & Mean & SD & $\begin{array}{l}\text { WHO } \\
(2004) \text { Std }\end{array}$ \\
\hline $\mathrm{pH}$ & & 38 & 6.59 & 7.26 & 6.91 & 0.19 & $6.5-8.5$ \\
Temp & ${ }^{\circ} \mathrm{C}$ & 38 & 27.5 & 30.9 & 29.43 & 0.11 & - \\
$\mathrm{EC}$ & $\mu \mathrm{S} / \mathrm{cm}$ & 38 & 62.5 & 83.6 & 71.01 & 5.50 & 1400 \\
$\mathrm{Salinity}$ & $\%$ o & 0.0 & 0.0 & 0.0 & 0.0 & 0.0 & - \\
$\mathrm{TDS}$ & $\mathrm{mg} / \mathrm{L}$ & 38 & 29.7 & 39.4 & 33.83 & 2.39 & 500 \\
$\mathrm{HCO}_{3}{ }^{-}$ & $\mathrm{mg} / \mathrm{L}$ & 38 & 23.16 & 46.33 & 35.31 & 3.71 & - \\
$\mathrm{Mg}^{2+}$ & $\mathrm{mg} / \mathrm{L}$ & 38 & 2.92 & 23.33 & 10.33 & 3.57 & 50 \\
$\mathrm{Na}^{+}$ & $\mathrm{mg} / \mathrm{L}$ & 38 & 7.9 & 11.0 & 8.77 & 0.76 & 200 \\
$\mathrm{Ca}^{2+}$ & $\mathrm{mg} / \mathrm{L}$ & 38 & 3.2 & 14.4 & 6.40 & 2.76 & 100 \\
$\mathrm{~K}^{+}$ & $\mathrm{mg} / \mathrm{L}$ & 38 & 4.0 & 5.9 & 5.2 & 0.35 & 12 \\
$\mathrm{Cl}^{-}$ & $\mathrm{mg} / \mathrm{L}$ & 38 & 1.99 & 13.99 & 4.9 & 2.96 & 250 \\
$\mathrm{NO}_{3}{ }^{-}$ & $\mathrm{mg} / \mathrm{L}$ & 38 & 1.11 & 24.89 & 11.89 & 9.33 & 50 \\
$\mathrm{SO}_{4}{ }^{2-}$ & $\mathrm{mg} / \mathrm{L}$ & 38 & 6.56 & 28.11 & 18.0 & 6.26 & 250 \\
$\mathrm{PO}_{4}{ }^{3-}$ & $\mathrm{mg} / \mathrm{L}$ & 38 & 1.44 & 11.67 & 5.23 & 3.2 & - \\
\hline
\end{tabular}

$N$ total number of data points, WHO Std World Health Organization standards, $S D$ standard deviation 

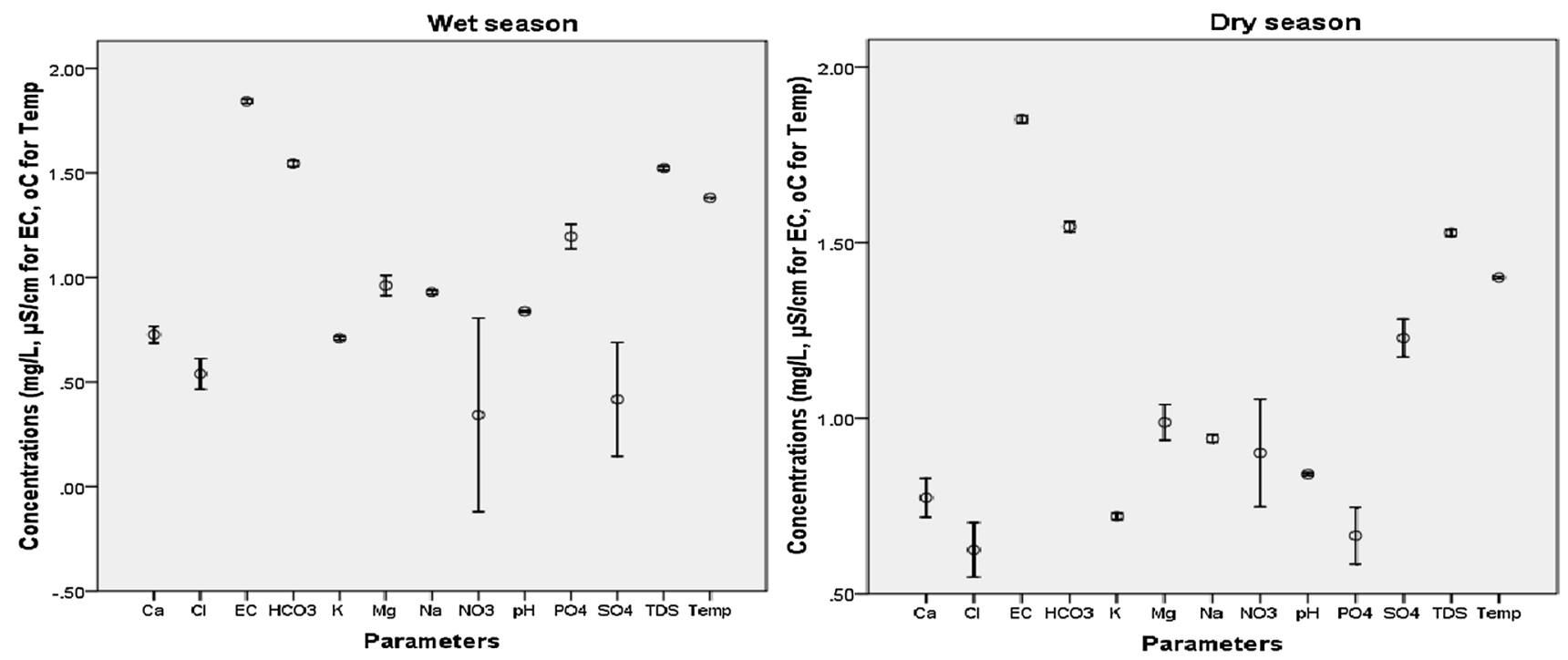

Fig. 3 Standard error bars presenting statistical description of physicochemical parameters for both seasons

problems and also endanger aquatic life if concentrations are above $5 \mathrm{mg} / \mathrm{L}$ (Morrison et al. 2001). About $35 \%$ of the sampling site had their concentrations above this level. The high levels of $\mathrm{PO}_{4}{ }^{3-}$ could originate from municipal wastewater discharges, since it is an important component of detergents. Non-point sources of phosphates may include natural decomposition of rocks and minerals, agricultural runoff, erosion and direct input by animals/ wildlife. It must be emphasized that average concentrations of some variables such as $\mathrm{pH}, \mathrm{EC}$, TDS, $\mathrm{HCO}_{3}{ }^{-}, \mathrm{Mg}^{2+}$, $\mathrm{Na}^{+}, \mathrm{K}^{+}, \mathrm{Cl}^{-}, \mathrm{Ca}^{2+}, \mathrm{NO}_{3}{ }^{-}$and $\mathrm{SO}_{4}{ }^{2-}$ contents of the river water were found within the limits set by the WHO (2004) standards for human consumption and domestic use (Tables 1,2). The low concentrations of these parameters could mean that less anthropogenic processes are occurring in the study area. It is also important to note that the excess $\mathrm{Na}^{+}$over $\mathrm{K}^{+}$could be attributed to the fact that $\mathrm{K}$-feldspar is more resistant to weathering than albite. The relatively low concentrations of $\mathrm{Mg}^{2+}, \mathrm{Na}^{+}, \mathrm{K}^{+}$and $\mathrm{Ca}^{2+}$ in the water samples are attributed to the fast mean annual flow of the lower Volta River $\left(298 \mathrm{~m}^{3} \mathrm{~s}^{-1}\right.$ ) (Opoku-Ankomah 1998). This probably caused less weathering of rocks containing these minerals, resulting in their low concentrations. Generally, the average physicochemical parameters showed slightly higher values in the dry season compared to the wet season, although $\mathrm{NO}_{3}{ }^{-}, \mathrm{SO}_{4}{ }^{2-}$ and $\mathrm{PO}_{4}{ }^{3-}$ differed in this sense (Tables 1, 2; Fig. 3). This may be due to the reduction of the water volume in the study area attributable to increase in temperature causing evaporation and resulting in higher concentrations.

Box plots of individual variables in both the wet and dry seasons were examined. Figure 4 shows examples of box plots for some meaningful variables related to the quality of the river water in the study area. The line across the box represents the median, whereas the bottom and top of the box show the locations of the first and third quartiles $\left(Q_{1}\right.$ and $Q_{3}$ ). The whiskers are the lines that extend from the bottom and top of the box to the lowest and highest observations inside the region defined by $\mathrm{Q}_{1}-1.5\left(Q_{3}-Q_{1}\right)$ and $Q_{3}-1.5\left(Q_{3}-Q_{1}\right)$. Individual points with values outside these limits (outliers) are plotted with asterisks. Box plots provide a visual impression of the location and shape of the underlying distributions. For example, box plots with long whiskers at the top of the box (such as that for $\mathrm{Cl}^{-}$in the dry season) indicate that the underlying distribution is skewed toward high concentration. Box plots with large spread indicate seasonal variations of the water composition (see $\mathrm{NO}_{3}{ }^{-}, \mathrm{PO}_{4}{ }^{3-}$ and $\mathrm{SO}_{4}{ }^{2-}$ box plots). The variability in the data of each parameter is also apparent in Fig. 4 as indicated by the position of the median bar and the relative lengths of the whiskers on both sides of the box of each of the parameters (Vega et al. 1998).

\section{Multivariate statistical analysis}

\section{Cluster analysis}

Cluster analysis allows the grouping of river water samples on the basis of their similarities in chemical composition. Unlike PCA that normally uses only two or three PCs for display purposes, cluster analysis uses all the variance or information contained in the original data set. Hierarchical agglomerative clustering by the Ward's method was selected for sample classification because it possesses a small space distorting effect, uses more information on cluster 

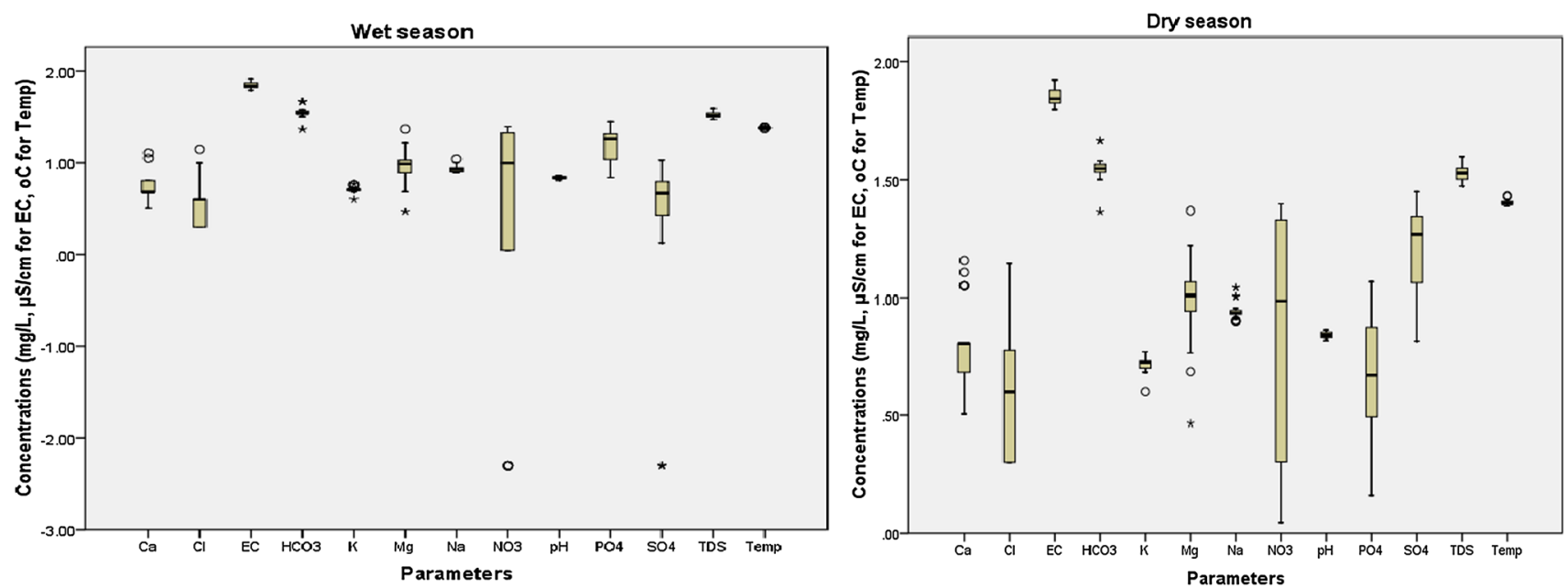

Fig. 4 Box plots for physicochemical parameters for both seasons

Fig. 5 A dendrogram of the measured parameters

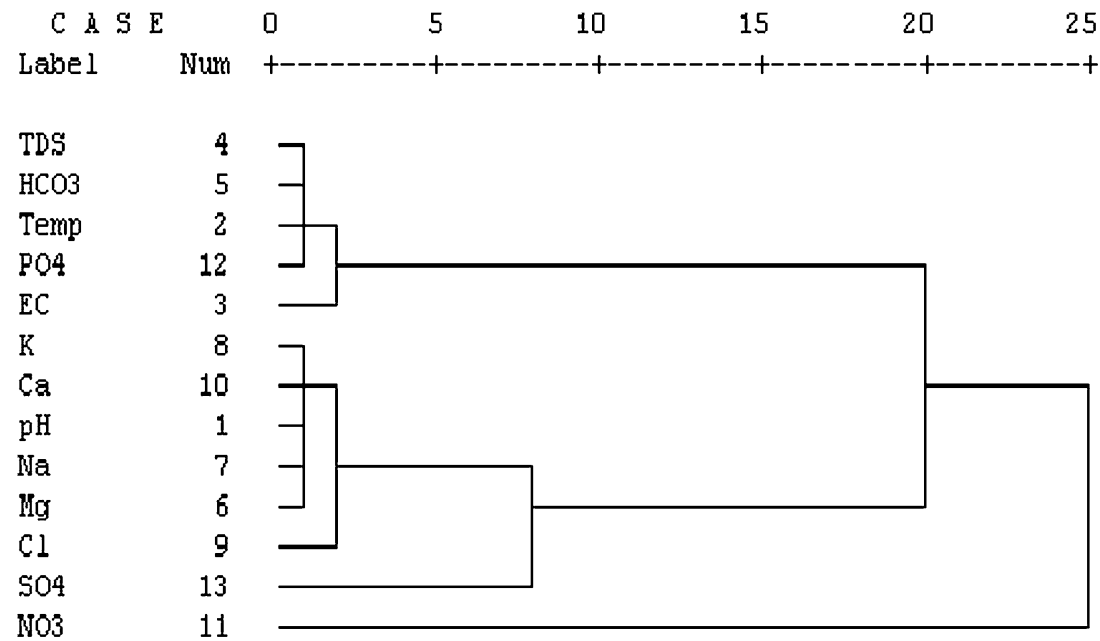

contents than other methods, and has been proved to be an extremely powerful grouping mechanism (Willet 1987); also, Ward's method yielded the most meaningful clusters. The method was applied to the normalized data using squared Euclidean distances as a measure of similarity (Massart and Kaufman 1983).

In the R-mode HCA, the dendrogram reveals three main water groups (Fig. 5). These groups, respectively, represent the effects of two main factors in the hydrochemistry: natural and anthropogenic factors. Group 1 indicates that $\mathrm{EC}$ in the water has a dominant contribution from the $\mathrm{HCO}_{3}{ }^{-}$in the water. It comprises TDS, $\mathrm{HCO}_{3}{ }^{-}, \mathrm{PO}_{4}{ }^{3-}$, temperature and EC. Group 1 represents the effect of precipitation on the water chemistry, domestic waste and the decay of organic matter which enriches the water with $\mathrm{HCO}_{3}{ }^{-}$ions. Group 2 is made up of $\mathrm{K}^{+}, \mathrm{Ca}^{2+}, \mathrm{pH}, \mathrm{Na}^{+}, \mathrm{Mg}^{2+}$ and $\mathrm{Cl}^{-}$and represents mineral water reaction and household wastewaters which contain high concentrations from salts and soaps in the study area. Group 3 comprises $\mathrm{SO}_{4}{ }^{2-}$ and $\mathrm{NO}_{3}{ }^{-}$which are derived from aquaculture activities and organic and artificial fertilizers from farmlands located along the banks of the river. The dendrogram for the Q-mode HCA is also presented in Fig. 6. In Fig. 6 it was realized that the sampling sites did not change significantly in terms of physicochemical parameters and indicated that there were no spatial and temporal characteristics among the sampling sites.

\section{Principal component analysis (PCA)/factor analysis (FA)}

The coefficient of correlation was worked out to understand the relationship between the various parameters and to test the significance of the models. Table 3 shows the correlation of the different parameters and some clear hydrochemical relationships can be readily inferred. High and positive correlation can be observed between $\mathrm{pH}$ and 
Fig. 6 A dendrogram based on concentrations of physicochemical parameters based on all the sampling sites

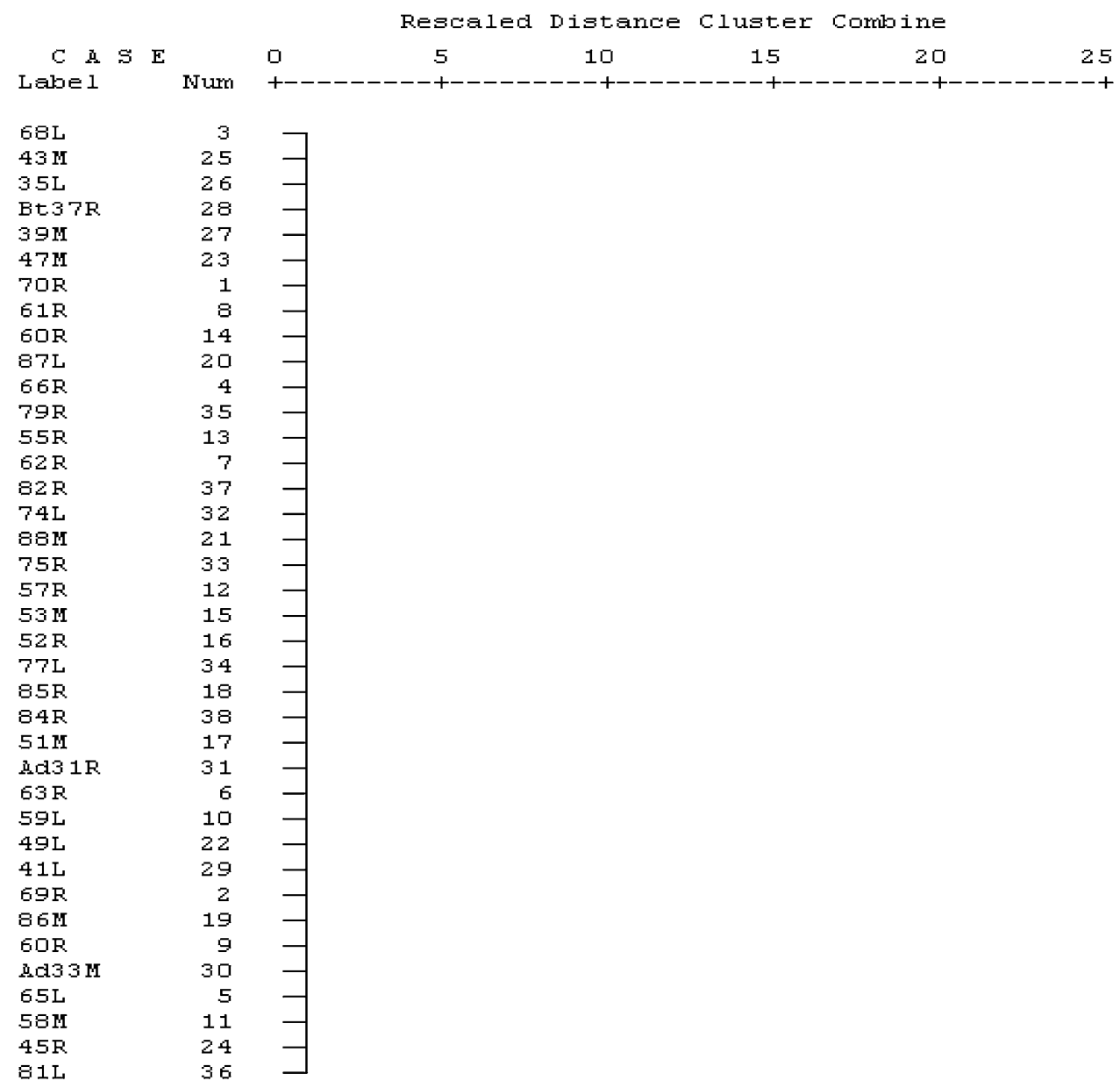

parameters. Four distinct factors have been discriminated based on the Kaiser criterion and explain $78.67 \%$ (Table 5) of the total variance in the hydrochemistry, suggesting that within the limits of the data obtained from the field, the most important processes are captured in the factor model. PC1 explains $29.41 \%$ of the variance and is highly contributed by EC, TDS, $\mathrm{Na}^{+}$and, to a less extent, by $\mathrm{NO}_{3}{ }^{-}$(Table 6). These variables were demonstrated to be correlated (Table 3). PC1 can thus be interpreted as including a mineral component of the river water, contribution of domestic wastewaters and organic matter in the study area. PC2 (19.96\% of the variance) is positively contributed to by $\mathrm{pH}$ and temperature (Table 6) which are also shown in Table 3. The $\mathrm{pH}$ is a measure of the acidity or basicity of water. The $\mathrm{pH}$ of a natural water can provide important information about many chemical and biological processes and provides indirect correlations to a number of different impairments.PC2 represents high biological activity (Saravanakumar et al. 2008) and less dilution of acid into the water, which can have an immediate or a long-term effect by influencing the chemical composition and $\mathrm{pH}$ fluctuations of the river water (Preda and Cox 2000; Abubacker et al. 1996) due to high temperature associated explained and the communalities of the individual 
Table 3 Correlation matrix of the 13 physicochemical parameters

\begin{tabular}{|c|c|c|c|c|c|c|c|c|c|c|c|c|c|}
\hline & $\mathrm{pH}$ & Temp & $\mathrm{EC}$ & TDS & $\mathrm{HCO}_{3}^{-}$ & $\mathrm{Mg}^{2+}$ & $\mathrm{Na}^{+}$ & $\mathrm{K}^{+}$ & $\mathrm{Cl}^{-}$ & $\mathrm{Ca}^{2+}$ & $\mathrm{NO}_{3}^{-}$ & $\mathrm{PO}_{4}{ }^{3-}$ & $\mathrm{SO}_{4}{ }^{2-}$ \\
\hline $\mathrm{pH}$ & 1 & 0.702 & 0.114 & 0.112 & -0.057 & -0.072 & 0.193 & -0.005 & 0.267 & -0.058 & 0.212 & -0.004 & 0.235 \\
\hline Temp & & 1 & 0.096 & 0.01 & 0.209 & -0.11 & 0.19 & -0.009 & 0.26 & -0.184 & 0.321 & -0.048 & 0.156 \\
\hline $\mathrm{EC}$ & & & 1 & 0.727 & 0.083 & -0.009 & 0.53 & 0.093 & 0.076 & -0.151 & 0.588 & -0.229 & 0.153 \\
\hline TDS & & & & 1 & 0.018 & -0.202 & 0.563 & 0.084 & 0.067 & 0.111 & 0.294 & -0.273 & 0.06 \\
\hline $\mathrm{HCO}_{3}{ }^{-}$ & & & & & 1 & -0.051 & -0.028 & 0.009 & -0.016 & -0.261 & 0.214 & 0.119 & 0.071 \\
\hline $\mathrm{Mg}^{2+}$ & & & & & & 1 & -0.167 & -0.066 & 0.137 & -0.514 & 0.089 & 0.155 & -0.017 \\
\hline $\mathrm{Na}^{+}$ & & & & & & & 1 & -0.054 & 0.141 & 0.068 & 0.07 & -0.229 & -0.035 \\
\hline $\mathrm{K}^{+}$ & & & & & & & & 1 & -0.157 & -0.051 & 0.062 & -0.059 & 0.085 \\
\hline $\mathrm{Cl}^{-}$ & & & & & & & & & 1 & -0.065 & 0.347 & 0.142 & 0.02 \\
\hline $\mathrm{Ca}^{2+}$ & & & & & & & & & & 1 & -0.515 & -0.115 & 0.279 \\
\hline $\mathrm{NO}_{3}^{-}$ & & & & & & & & & & & 1 & 0.18 & -0.09 \\
\hline $\mathrm{PO}_{4}{ }^{3-}$ & & & & & & & & & & & & 1 & 0.091 \\
\hline $\mathrm{SO}_{4}{ }^{2-}$ & & & & & & & & & & & & & 1 \\
\hline
\end{tabular}

Table 4 Correlation matrix for some sampling sites based on physicochemical parameters

\begin{tabular}{|c|c|c|c|c|c|c|c|c|c|c|c|c|c|c|c|c|c|c|c|c|c|c|}
\hline & $70 \mathrm{R}$ & $68 \mathrm{~L}$ & $65 \mathrm{~L}$ & $62 \mathrm{R}$ & $60 \mathrm{R}$ & $58 \mathrm{M}$ & $55 \mathrm{R}$ & $53 \mathrm{M}$ & $51 \mathrm{M}$ & $86 \mathrm{M}$ & $88 \mathrm{M}$ & $47 \mathrm{M}$ & $43 \mathrm{M}$ & $39 \mathrm{M}$ & $41 \mathrm{~L}$ & Ad33 M & Ad31R & $75 \mathrm{R}$ & $77 \mathrm{~L}$ & $79 \mathrm{R}$ & $81 \mathrm{~L}$ & $84 \mathrm{~L}$ \\
\hline $70 \mathrm{R}$ & 1.00 & 0.95 & 0.79 & 0.96 & 0.96 & 0.96 & 0.97 & 0.92 & 0.84 & 0.96 & 0.78 & 0.94 & 0.98 & 0.78 & 0.95 & 0.97 & 0.98 & 0.99 & 0.99 & 0.95 & 0.86 & 0.77 \\
\hline $68 \mathrm{~L}$ & & 1.00 & 0.90 & 0.91 & 0.93 & 0.91 & 0.91 & 0.93 & 0.79 & 0.90 & 0.86 & 0.93 & 0.94 & 0.86 & 0.89 & 0.92 & 0.93 & 0.97 & 0.97 & 0.92 & 0.79 & 0.88 \\
\hline $65 \mathrm{~L}$ & & & 1.00 & 0.95 & 0.95 & 0.95 & 0.96 & 0.91 & 0.84 & 0.94 & 0.79 & 0.90 & 0.97 & 0.80 & 0.97 & 0.99 & 0.97 & 0.97 & 0.98 & 0.95 & 0.86 & 0.76 \\
\hline $62 \mathrm{R}$ & & & & 1.00 & 0.99 & 0.99 & 0.99 & 0.93 & 0.83 & 0.99 & 0.70 & 0.89 & 0.92 & 0.73 & 0.96 & 0.91 & 0.97 & 0.95 & 0.96 & 0.92 & 0.85 & 0.76 \\
\hline $60 R$ & & & & & 1.00 & 0.99 & 0.98 & 0.97 & 0.84 & 0.98 & 0.76 & 0.91 & 0.93 & 0.79 & 0.96 & 0.92 & 0.98 & 0.97 & 0.97 & 0.94 & 0.87 & 0.82 \\
\hline $58 \mathrm{M}$ & & & & & & 1.00 & 0.99 & 0.95 & 0.85 & 0.99 & 0.71 & 0.90 & 0.94 & 0.73 & 0.96 & 0.91 & 0.98 & 0.96 & 0.96 & 0.95 & 0.88 & 0.77 \\
\hline $55 \mathrm{R}$ & & & & & & & 1.00 & 0.94 & 0.85 & 1.00 & 0.72 & 0.91 & 0.93 & 0.75 & 0.96 & 0.93 & 0.98 & 0.97 & 0.97 & 0.93 & 0.88 & 0.77 \\
\hline $53 \mathrm{M}$ & & & & & & & & 1.00 & 0.83 & 0.94 & 0.82 & 0.88 & 0.92 & 0.83 & 0.94 & 0.89 & 0.95 & 0.94 & 0.94 & 0.95 & 0.85 & 0.89 \\
\hline $51 \mathrm{M}$ & & & & & & & & & 1.00 & 0.84 & 0.76 & 0.70 & 0.79 & 0.76 & 0.86 & 0.82 & 0.85 & 0.83 & 0.82 & 0.78 & 0.97 & 0.73 \\
\hline $86 \mathrm{M}$ & & & & & & & & & & 1.00 & 0.70 & 0.89 & 0.91 & 0.73 & 0.95 & 0.90 & 0.97 & 0.95 & 0.95 & 0.91 & 0.87 & 0.76 \\
\hline $88 \mathrm{M}$ & & & & & & & & & & & 1.00 & 0.72 & 0.79 & 0.99 & 0.82 & 0.83 & 0.75 & 0.79 & 0.82 & 0.77 & 0.67 & 0.95 \\
\hline $47 \mathrm{M}$ & & & & & & & & & & & & 1.00 & 0.91 & 0.72 & 0.84 & 0.90 & 0.89 & 0.97 & 0.94 & 0.90 & 0.78 & 0.75 \\
\hline $43 \mathrm{M}$ & & & & & & & & & & & & & 1.00 & 0.78 & 0.93 & 0.96 & 0.97 & 0.96 & 0.97 & 0.97 & 0.81 & 0.77 \\
\hline $39 \mathrm{M}$ & & & & & & & & & & & & & & 1.00 & 0.84 & 0.83 & 0.77 & 0.79 & 0.83 & 0.76 & 0.67 & 0.96 \\
\hline $41 \mathrm{~L}$ & & & & & & & & & & & & & & & 1.00 & 0.95 & 0.96 & 0.93 & 0.96 & 0.93 & 0.85 & 0.82 \\
\hline $\operatorname{Ad} 33 \mathrm{M}$ & & & & & & & & & & & & & & & & 1.00 & 0.95 & 0.95 & 0.97 & 0.93 & 0.83 & 0.78 \\
\hline $\operatorname{Ad} 31 \mathrm{R}$ & & & & & & & & & & & & & & & & & 1.00 & 0.97 & 0.97 & 0.96 & 0.88 & 0.78 \\
\hline $75 \mathrm{R}$ & & & & & & & & & & & & & & & & & & 1.00 & 0.99 & 0.95 & 0.88 & 0.80 \\
\hline $77 \mathrm{~L}$ & & & & & & & & & & & & & & & & & & & 1.00 & 0.96 & 0.84 & 0.83 \\
\hline $79 R$ & & & & & & & & & & & & & & & & & & & & 1.00 & 0.82 & 0.79 \\
\hline $81 \mathrm{~L}$ & & & & & & & & & & & & & & & & & & & & & 1.00 & 0.67 \\
\hline $84 \mathrm{~L}$ & & & & & & & & & & & & & & & & & & & & & & 1.00 \\
\hline
\end{tabular}

Table 5 Extraction values of the total variance using PCA for nine water quality parameters

\begin{tabular}{|c|c|c|c|c|c|c|}
\hline \multirow[t]{2}{*}{ Component } & \multicolumn{3}{|c|}{ Initial eigenvalues } & \multicolumn{3}{|c|}{ Extraction sums of squared loadings } \\
\hline & Total & $\%$ of variance & Cumulative $\%$ & Total & $\%$ of variance & Cumulative $\%$ \\
\hline 1 & 2.647 & 29.408 & 29.408 & 2.647 & 29.408 & 29.408 \\
\hline 2 & 1.797 & 19.964 & 49.372 & 1.797 & 19.964 & 49.372 \\
\hline 3 & 1.622 & 18.026 & 67.398 & 1.622 & 18.026 & 67.398 \\
\hline 4 & 1.016 & 11.288 & 78.686 & 1.016 & 11.288 & 78.686 \\
\hline
\end{tabular}


Table 6 Loadings of nine experimental variables on four significant principal components for river water samples in the study area

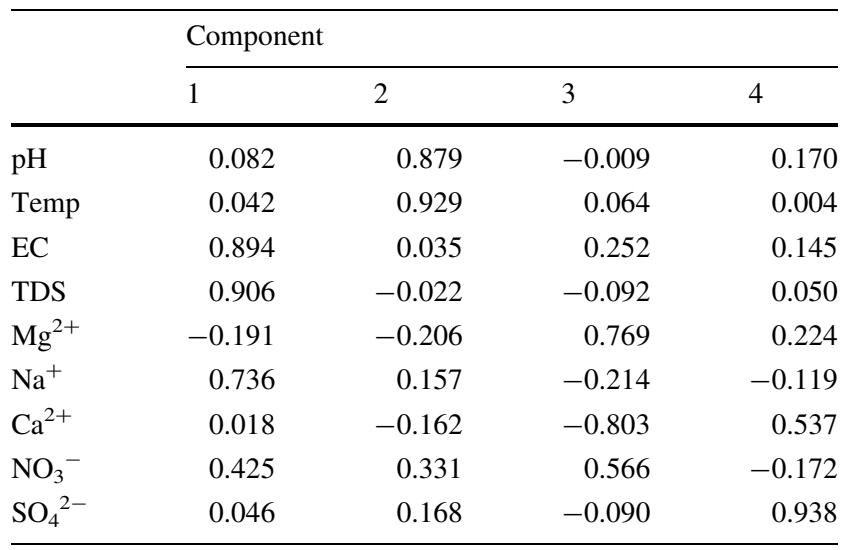

Extraction method: principal component analysis. Rotation method: Varimax with Kaiser normalization

with the dry season. PC3 represents $18.03 \%$ of the total variance (Table 5) with high positive loadings for $\mathrm{Mg}^{2+}$ and $\mathrm{NO}_{3}{ }^{-}$and high negative loadings for $\mathrm{Ca}^{2+}$ (Table 6). PC4 explains $11.29 \%$ of the total variance and has high $\mathrm{Ca}^{2+}$ and $\mathrm{SO}_{4}{ }^{2-}$. PC3 and PC4 variables were also corroborated (Table 3 ). This clustering of variables points to a common origin for these minerals, likely from dissolution of limestone, marl and gypsum soils. Factors 3 and 4 also suggest contamination from anthropogenic activities specifically from surface contamination processes, such as agricultural chemicals used on rice farms in the area to enhance yields.

\section{Suitability of river water for irrigation}

Poor-quality water may affect irrigated crops by causing accumulation of salts in the root zone and loss of permeability of the soil due to excess sodium or calcium leaching, or by containing contaminants which are directly toxic to plants or to those consuming them. Contaminants in irrigation water may accumulate in the soil and, after a period of years, render the soil unfit for agriculture. Even when the presence of pesticides or pathogenic organisms in irrigation water does not directly affect plant growth, it may potentially affect the acceptability of the agricultural product for sale or consumption.

The effect of salinity on the osmotic pressure in the unsaturated soil zone is one of the most important water quality considerations, because this has an influence on the availability of water for plant consumption. All the samples had $0 \%$ (Tables 1,2$)$ salinity in the study area, suggesting that salinity has no influence and water will be readily available for plant consumption. High sodium concentrations in irrigation waters can adversely affect soil structure and reduce the rate at which water moves into and through soils. Sodium is also a specific source of damage to fruits (FAO 1985). Sodium concentrations were low and ranged from 7.8 to $11.0 \mathrm{mg} / \mathrm{L}$ (Tables 1,2 ); thus in terms of sodium measurements, the water samples in the area are good for irrigation purposes. Water with TDS less than $450 \mathrm{mg} / \mathrm{L}$ is considered good and that with greater than $2000 \mathrm{mg} / \mathrm{L}$ is unsuitable for agricultural purposes (Ayers and Westcot 1985). In the study area, TDS ranges from 29.7 to $39.4 \mathrm{mg} / \mathrm{L}$ (Tables 1,2 ). Also, water salinity hazards are measured using EC. If EC is greater than $3000 \mu \mathrm{S} /$ $\mathrm{cm}$, then crop productivity is affected very much; it is good if EC is $250 \mu \mathrm{S} / \mathrm{cm}$ (Ayers and Westcot 1985). If EC increases, water intake by the plant significantly decreases and, hence, the productivity is also considerably reduced. In our study area, EC varied from 61.7 to $83.6 \mu \mathrm{S} / \mathrm{cm}$ (Tables 1,2); thus based on these values, the river water can be considered to be good for irrigation.

Another index is sodium adsorption ratio (SAR) which measures the suitability of water for use in agricultural irrigation, because sodium concentration can reduce soil permeability and soil structure (Todd 1980). SAR is a measure of alkali/sodium hazard to crops and it was estimated by the following formula:

$\mathrm{SAR}=\frac{\mathrm{Na}^{+}}{\sqrt{\frac{\left(\mathrm{Ca}^{2+}+\mathrm{Mg}^{2+}\right)}{2}}}$,

where sodium, calcium and magnesium are in meq/L. The SAR value of water for irrigation purposes has a significant relationship with the extent to which sodium is absorbed by the soils. Irrigation using water with high SAR values may require soil amendments to prevent long-term damage to the soil, because the sodium in the water can displace the calcium and magnesium in the soil. This will cause a decrease in the ability of the soil to form stable aggregates and loss of soil structure. This will also lead to a decrease in infiltration and permeability of the soil to water, leading to problems with crop production. The calculated values of SAR in the study area vary between 0.69 and 2.17 (Table 7; Fig. 7). The classification of water samples based on SAR values reported by Todd (1959) and Richards (1954) are as follows: excellent $(<10)$, good $(10-18)$, doubtful (18-26) and unsuitable ( $>26)$. The SAR values of all the samples (100\%) are found within the range of excellent, which is found to be suitable for irrigation purposes. For rating irrigation waters, the United State salinity diagram (USSL) was used, in which the SAR was plotted against EC (Fig. 7). Both axes are divided into four major sections: S1-S4 for low to very high sodicity (SAR) and C1-C4 for low to very high salinity, respectively. The USSL (1954) plot (Fig. 7) indicates that all the river water samples $(100 \%)$ fall in C1-S1 (low salinity-low sodium type) category representing waters of acceptable quality for 
irrigation activities, because such waters do not cause $\mathrm{Na}$ permeability effects resulting from high exchangeable $\mathrm{Na}$ percentage.

\section{Magnesium ratio (MR)}

In natural waters, $\mathrm{Mg}^{2+}$ in equilibrium state will adversely affect crop yields. The MR of irrigation water is proposed by Szabolcs and Darab (1964) and presented in Eq. 5:

$\mathrm{MR}=\frac{\mathrm{Mg}^{2+} \times 100}{\mathrm{Ca}^{2+}+\mathrm{Mg}^{2+}}$.

MR values exceeding $50 \%$ is considered harmful and unsuitable for irrigational use. In the analyzed river water samples, it is found between 27.3 and 88.89 with a mean of 72.95 (Table 7). In the study area, $97 \%$ of the samples collected showed MR ratio $>50 \%$ (unsuitable for irrigation) and $3 \%$ in the suitable category with $\mathrm{MR}<50 \%$. The evaluation illustrates that $\mathrm{Ca}^{2+}$ and $\mathrm{Mg}^{2+}$ do not maintain a state of equilibrium in river water and could be due to the high concentration of $\mathrm{Mg}^{2+}$ as compared to $\mathrm{Ca}^{2+}$ (Tables 1,2 ). The inverse relationship between $\mathrm{Mg}^{2+}$ and $\mathrm{Ca}^{2+}$ was also evident in Tables 3 and 6 .

Table 7 Irrigation quality parameters of river water samples

\begin{tabular}{lccrr}
\hline & Minimum & Maximum & Mean & \multicolumn{1}{c}{ SD } \\
\hline SAR (Meq/L) & 0.69 & 2.17 & 1.44 & 0.32 \\
MR (\%) & 27.29 & 88.88 & 72.94 & 10.68 \\
PI (\%) & 52.38 & 121.35 & 93.81 & 15.38 \\
KR (Meq/L) & 0.83 & 3.47 & 2.23 & 0.53 \\
\hline
\end{tabular}

\section{Permeability index (PI)}

Continuous usage of water for irrigation will affect the permeability quality of the soil. It is influenced by $\mathrm{Na}^{+}$, $\mathrm{Ca}^{2+}, \mathrm{Mg}^{2+}$ and $\mathrm{HCO}_{3}{ }^{-}$contents in soil. Doneen (1964) has shown the suitability of water for irrigation based on the permeability index (PI) which is presented in Eq. 6 as follows:

$\mathrm{PI}=\frac{\left(\mathrm{Na}^{+}+\sqrt{\mathrm{HCO}_{3}^{-}}\right)}{\sqrt{\left(\mathrm{Ca}^{2+}+\mathrm{Mg}^{2+}+\mathrm{Na}^{+}\right)}} \times 100$.

According to the classification by Doneen (1964), Class I and II ( $>75 \%)$ pose maximum permeability and are good for irrigation, while Class III $(<25 \%)$ shows maximum permeability and is unsuitable for irrigation purposes. In the present study, PI values range from 52 to 121 (Table 7). On the bases of PI classification, the river water in the study area fall under Class II; hence, the water is considered for irrigation.

\section{Kelley's ratio (KR)}

Kelly (1951) has suggested that the sodium problem in irrigation water could be very conveniently worked on the basis of the values of Kelly's ratio. In general, water with Kelly's ratio greater than one is unfit for irrigation.

Kelly's ratio is presented in Eq. 7 as follows:

$$
\mathrm{KR}=\frac{\mathrm{Na}^{+}}{\mathrm{Ca}^{2+}+\mathrm{Mg}^{2+}} \text {. }
$$

KR calculated for our study area ranged from 0.83 to $3.5 \mathrm{meq} / \mathrm{L}$ (Table 7). About $31 \%$ of the water samples
Fig. 7 USSL diagram for SAR and EC for samples at the study area

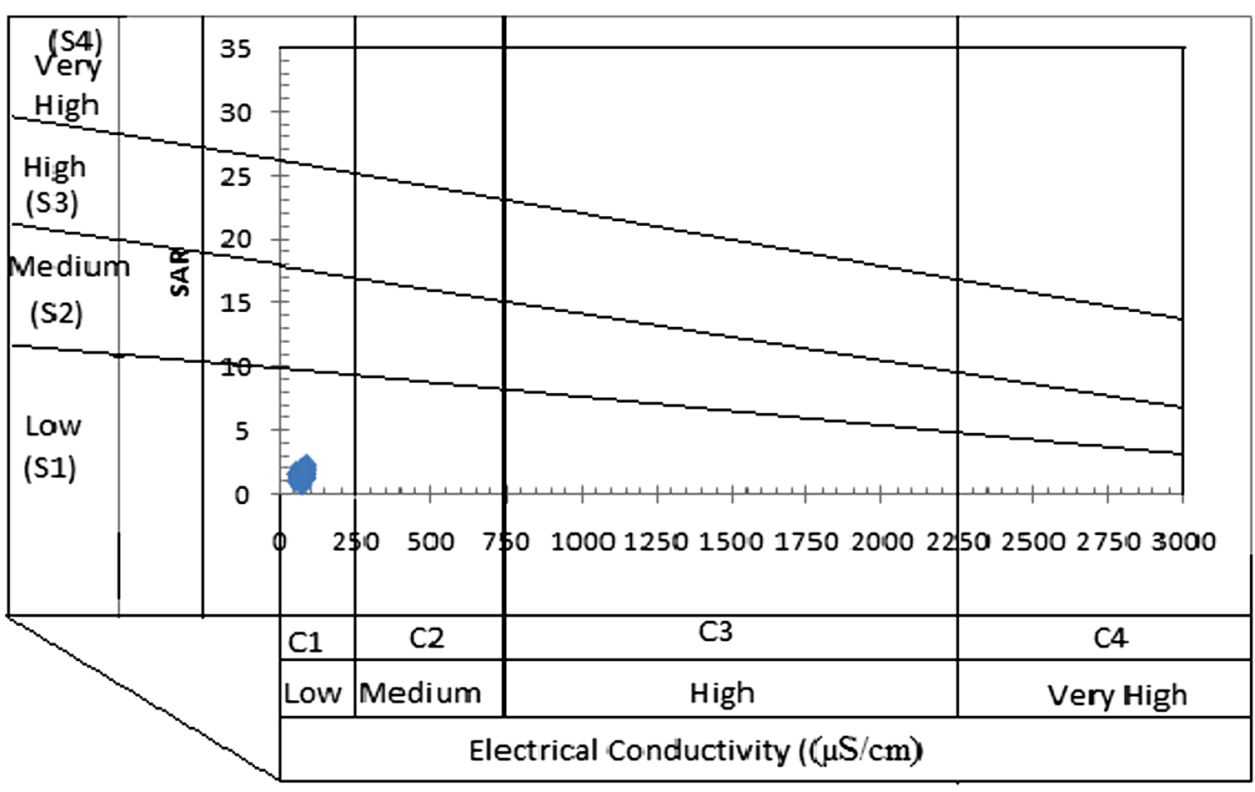


recorded $\mathrm{KR}$ values $<1$ which are suitable for irrigation. The rest of the water samples $(69 \%)$ had their KR values above 1 which are unsuitable for irrigational purposes.

\section{Stable isotope hydrology}

Environmental isotopes, such as oxygen-18 and deuterium, are compositions of water molecules and they approximate water behaviors (Clark and Fritz 1997) and serve as suitable tools for tracing water pathways and contributions. Stable isotopic compositions of water are constantly fractionated by temperature, season and evaporation effects. The results and statistical summary of stable isotopic composition of the Volta River and stream water samples in the study area are presented in Tables 8 and 9. The stable isotope data are expressed as per mil deviations from the VSMOW standard.

Values of $\delta^{18} \mathrm{O}$ for the Volta River samples in the study area ranged from +2.52 to $+7.69 \%$ vs VSMOW with a mean value of $+5.70 \%$ vs VSMOW (Table 9). The $\delta^{2} \mathrm{H}$ also ranged from +5.18 to $+16.2 \%$ vs VSMOW with a mean value of $+11.85 \%$ vs VSMOW (Table 9). The values are narrowly spread showing that the Volta River is homogeneous in isotopic composition. The $\delta^{18} \mathrm{O}$ and $\delta^{2} \mathrm{H}$ content of the Volta River water are much enriched and this can be attributed to the fact that, being a large open river, it might have been subjected to high level of evaporation and also due to deforestation along the banks of the river. It was observed by Akiti (1980) that the $\delta^{18} \mathrm{O}$ content at Yapei in the Northern Region of Ghana was $1.10 \%$ and it was $+0.7 \%$ VSMOW at Akosombo in Southern Ghana. This suggests that isotopic enrichment occurs as one moves toward the southern parts of the Volta River. This is in tandem with observed trends in the study area.

The isotopic content of any river is the contributions of the various tributaries and their geographic locations. Stream samples from Canal (S1), Lome (S2), Odzador (S3) and Okue (S4) were evaluated for stable isotope analysis. The $\delta^{18} \mathrm{O}$ values were $-1.25,-0.90,-1.26$ and $-0.53 \%$ vs VSMOW for S1, S2, S3 and S4, respectively, while the $\delta^{2} \mathrm{H}$ values were $-3.53,+0.58,-3.13$ and $+1.89 \%$ vs VSMOW, respectively (Table 8 ). These values indicate that the stream waters are relatively depleted in these isotopes $\left(\delta^{18} \mathrm{O}\right.$ and $\left.\delta^{2} \mathrm{H}\right)$. Figure 8 shows the relationship between $\delta^{2} \mathrm{H}$ and $\delta^{18} \mathrm{O}$ isotopic composition for the Akiti's Line (LMWL), GMWL, river water and stream water samples, respectively. It evidences that the narrow scattered river water samples had undergone some degree of evaporation as a result of non-equilibrium process (kinetic) fractionation and therefore plot below the meteoric line.
Table 8 Stable isotope results of river water samples and some streams in the study area

\begin{tabular}{|c|c|c|}
\hline Sample code & $\delta^{2} \mathrm{H}(\% 0)$ & $\delta^{18} \mathrm{O}(\%)$ \\
\hline $70 \mathrm{R}$ & +10.39 & +5.16 \\
\hline $69 \mathrm{R}$ & +10.08 & +4.97 \\
\hline $68 \mathrm{~L}$ & +10.91 & +4.93 \\
\hline $66 \mathrm{R}$ & +11.13 & +5.43 \\
\hline $65 \mathrm{~L}$ & +13.05 & +6.61 \\
\hline $63 \mathrm{R}$ & +13.57 & +6.79 \\
\hline $62 \mathrm{R}$ & +12.95 & +6.18 \\
\hline $61 \mathrm{R}$ & +13.93 & +5.69 \\
\hline $60 \mathrm{R}$ & +14.03 & +6.85 \\
\hline $59 \mathrm{~L}$ & +14.15 & +6.59 \\
\hline $58 \mathrm{M}$ & +14.36 & +6.78 \\
\hline $57 \mathrm{R}$ & +15.47 & +6.95 \\
\hline $55 \mathrm{R}$ & +15.17 & +6.53 \\
\hline $54 \mathrm{~L}$ & +10.49 & +4.97 \\
\hline $53 \mathrm{M}$ & +10.68 & +5.49 \\
\hline $52 \mathrm{R}$ & +10.79 & +4.53 \\
\hline $51 \mathrm{M}$ & +10.95 & +4.93 \\
\hline $49 \mathrm{~L}$ & +16.20 & +7.69 \\
\hline $47 \mathrm{M}$ & +15.47 & +7.12 \\
\hline $45 \mathrm{R}$ & +10.56 & +5.55 \\
\hline $43 \mathrm{M}$ & +9.74 & +4.82 \\
\hline $35 \mathrm{~L}$ & +12.6 & +5.88 \\
\hline $39 \mathrm{M}$ & +12.01 & +5.92 \\
\hline Bt37R & +9.67 & +5.53 \\
\hline $41 \mathrm{~L}$ & +8.59 & +4.70 \\
\hline $\operatorname{Ad} 33 \mathrm{M}$ & +9.11 & +4.66 \\
\hline $\operatorname{Ad} 31 \mathrm{R}$ & +12.05 & +5.61 \\
\hline $74 \mathrm{~L}$ & +12.53 & +6.19 \\
\hline $75 \mathrm{R}$ & +13.16 & +5.56 \\
\hline $77 \mathrm{~L}$ & +9.70 & +5.03 \\
\hline $79 \mathrm{R}$ & +12.42 & +4.84 \\
\hline $81 \mathrm{~L}$ & +11.27 & +5.87 \\
\hline $82 \mathrm{R}$ & +15.14 & +6.35 \\
\hline $84 \mathrm{~L}$ & +11.16 & +5.61 \\
\hline $85 \mathrm{R}$ & +5.18 & +2.52 \\
\hline $86 \mathrm{M}$ & +9.89 & +5.59 \\
\hline $87 \mathrm{~L}$ & +10.92 & +6.07 \\
\hline $88 \mathrm{M}$ & +10.74 & +6.12 \\
\hline $\mathrm{S} 1$ & -3.53 & -1.25 \\
\hline $\mathrm{S} 2$ & +0.58 & -0.90 \\
\hline $\mathrm{S} 3$ & -3.13 & -1.26 \\
\hline $\mathrm{S} 4$ & +1.89 & -0.53 \\
\hline
\end{tabular}

The point of intersection for the evaporative line and LMWL corresponded to $-3.40 \%$ vs VSMOW on the $\delta$ ${ }^{18} \mathrm{O} \%$ axis (Fig. 8). This may indicate the isotopic composition of the rainfall source from which the evaporated 
Table 9 Statistical summary of stable isotope results of water samples in the area

\begin{tabular}{llrlllll}
\hline $\begin{array}{l}\text { Permil } \\
(\%)\end{array}$ & Water & $N$ & Min & Max & Mean & Median & SD \\
\hline$\delta^{18} \mathrm{O}$ & Volta River & 38 & +2.52 & +7.69 & +5.70 & +5.61 & 0.95 \\
& Stream waters & 4 & -0.53 & -1.26 & -0.99 & -1.08 & 0.35 \\
$\delta^{2} \mathrm{H}$ & Volta River & 38 & +5.18 & +16.2 & +11.85 & +11.22 & 2.28 \\
& Stream waters & 4 & -3.53 & +1.89 & -1.05 & -1.28 & 2.69 \\
\hline
\end{tabular}

water originated prior to experiencing kinetic fractionation effects, which slightly conforms with the average stable isotope composition of the rain that fell in the upper reaches of the Volta Basin which was $-3.75 \%$ vs VSMOW as reported by Akiti (1980). The relatively depleted nature of the stream waters may be due to the natural flow of water from the Akwapim Mountains (located at the western part of the Volta River) and rainfall, which are themselves depleted, and also the forested area, from which the samples for the streams were taken as the streams were not much exposed to sunlight causing evaporation. These stream waters are subjected to evaporation as they flow toward the Volta River, but it was observed that the evaporation was not as high as that of the Volta River.

\section{Conclusion}

Water quality data of a river were analyzed by unsupervised pattern recognition (HCA) and display methods (PCA) to extract correlations and similarities between variables and to classify river water samples into groups with similar quality. Q-mode HCA and correlation analysis indicate that the sampling sites did not differ significantly in relation to hydrochemical parameters. Hence, the above results will aid in designing an optimal temporal and spatial monitoring plan with a sharply reduced number of monitoring periods and sites and corresponding costs (Simeonov et al. 2003; Singh et al. 2005). A varimax rotation of these PCs led to a reduced number of factors, each of them related to a small group of experimental variables with a hydrochemical meaning: mineral contents for factor one, water temperature for factor two and anthropogenic activities for factors three and four. The assessment of river water for irrigation has been evaluated by standard guidelines. Hundred percent $(100 \%)$ of the data points fall in C1-S1 (low salinity-low sodium type) fields of the USSL (1954) SAR-EC categorization scheme for irrigation waters. On the basis of this, river water from the study area appears to be of good irrigation quality. PI supports this finding, as all the samples fall in Class II revealing suitability for irrigation. MR and KR had 3 and $31 \%$ of the river water samples suitable for irrigation purposes, respectively. The study reveals that the river water requires a special type of irrigation method to control the low ions that will improve the yield of crop production. Analysis of stable isotopes $\left(\delta^{18} \mathrm{O}\right.$ and $\left.\delta^{2} \mathrm{H}\right)$ in the study area shows that the Volta River water is undergoing evaporative processes and is enriched in heavy isotopes. In contrast, stream waters joining the much evaporated Volta River are depleted in terms of the heavier isotopes. The stream waters are therefore isotopically lighter than the isotopically heavy waters of the Volta River. This difference could be due to natural flow of water from the Akwapim Mountains and rainfall which are depleted in these isotopes but recharge the streams. This research work will aid in the development and management of surface water resources for domestic consumption, agricultural purposes and isotopic study and update in the area.
Fig. 8 A graph of $\delta^{2} \mathrm{H}$ against $\delta^{18} \mathrm{O}$

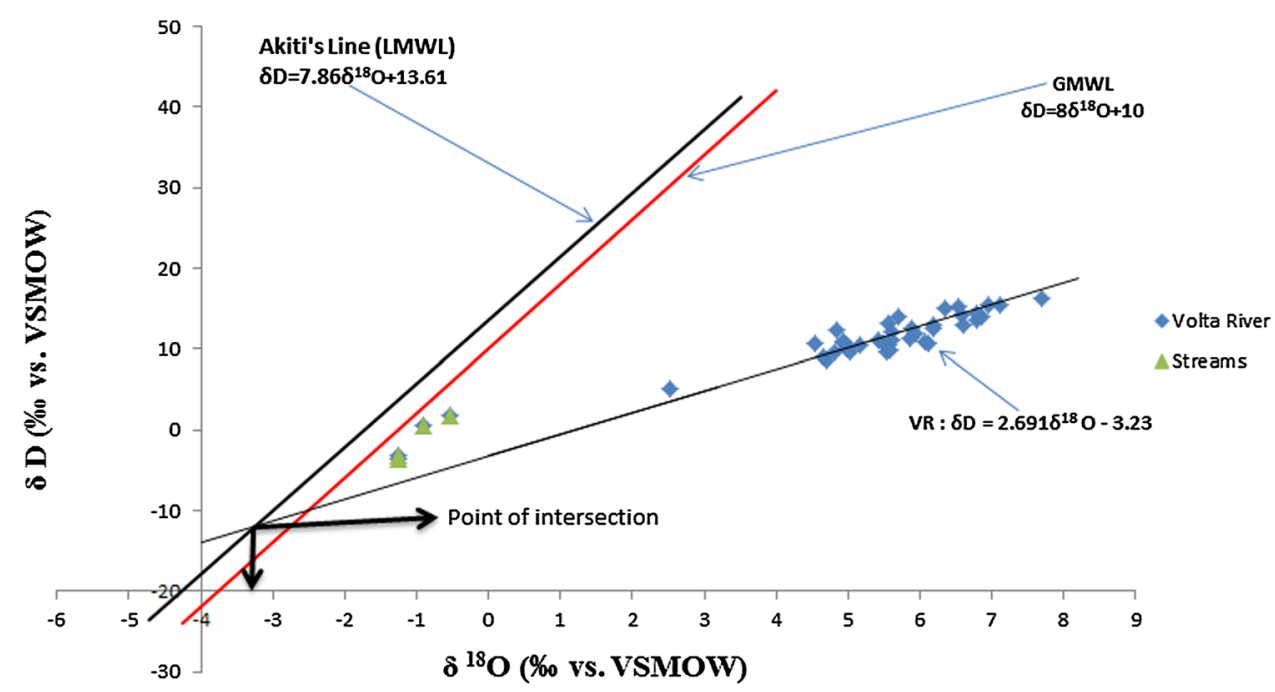


Open Access This article is distributed under the terms of the Creative Commons Attribution 4.0 International License (http:// creativecommons.org/licenses/by/4.0/), which permits unrestricted use, distribution, and reproduction in any medium, provided you give appropriate credit to the original author(s) and the source, provide a link to the Creative Commons license, and indicate if changes were made.

\section{References}

Abubacker MN, Kannan V, Sridharan VT, Chandramohan M, Rajavelu S (1996) Physico-chemical and biological studies on Uyya Kondan Canal water of river Cauvery. Pollut Res 15(3):257-259

Adams S, Titus R, Pietersen K, Tredoux G, Harris C (2001) Hydrochemical characteristics of aquifers near Sutherland in western Karoo, South Africa. J Hydrol 241(1-2):91-103

Akiti TT (1977) Groundwater flow in weathered granite in the Tamne basin, North Eastern Ghana

Akiti TT (1980) Etudé géochimique et isotopique de quelqués aquifers du Ghana. (Thesis) Univeristé Paris-Sud, p 232

Akiti TT (1987) Environmental isotope study of groundwater in crystalline rocks of the Accra Plains (Ghana). In: Wand U, Strauch G (eds) Isotopes in nature. Academy of Sciences of the GDR, Central Institute of Isotope and Radiation Research, Leizig, pp 107-121

Alberto WD, del Pilar DM, Valeria AM, Fabiana PS, Cecilia HA, de los Angles BM (2001) Patterns recognition techniques for the evaluation of spatial and temporal variations in water quality, a case study: Suquia River Basin (Cordoba-Argentina). Water Res 35:2881-2894

APHA, Awwa (1998) Standard methods for the examination of water and wastewater, 20th edn. American Public Health Association, New York

Ashley RP, Lloyd JW (1978) An example of the use of factor and cluster analysis in groundwater chemistry interpretation. J Hydrol 39:355-364

Ayers RS, Westcot DW (1985) Water quality for agriculture, vol 29. FAO irrigation and drainage, Rome, rev 1, p 174

Birke M, Rauch U (1993) Environmental aspects of the regional geochemical survey in the southern part of East Germany. J Geoch Expl 49(1-2):35-61

Briz-Kishore BH, Murali G (1992) Factor analysis for revealing hydrochemical characteristics of a watershed. Env Geol Wat Sci 19(1):3-9

Brown CE (1998) Applied multivariate statistics in geohydrology and related sciences. Springer, Berlin, p 248

Ceron JC, Pulido-Bosch A, Bakalowicz M (1999) Application of principal component analysis to the study of $\mathrm{CO}_{2}$-rich thermomineral waters in the aquifer system of Alto Guadalentin (Spain). Hydrol Sci 44(6):929-942

Clark I, Fritz P (1997) Environmental isotopes in hydrogeology. Lewis Publishers, Boca Raton, p 328

Craig H (1961) Isotopic variations in meteroic water. Science 133:1702-1703

Coleman ML, Shepherd TJ, Durham JJ, Rouse JE, Moore GR (1982) Reduction of water with zinc for hydrogen isotope analysis. Anal Chem 54:993-995

Community Water and Sanitation Agency (CWSA) (2005) Annual report ministry of water resources. Works and Housing Accra, Ghana, p 67

Coplen TB (1988) Normalization of oxygen and hydrogen isotope data. Chem Geol 72:293-297
Dalton MG, Upchurch SB (1978) Interpretation of hydrochemical facies by factor analysis. Groundwater 16(4):228-233

Doneen LD (1964) Notes on water quality in agriculture. Water science and engineering. University of California, Davis

Edmunds WM, Walton NRC (1980) A geochemical and isotopic approach to recharge evaluation in semi-arid zones. In: Proceedings of the advisory group meeting on the application of isotope techniques in Arid zone Hydrology, Vienna, i978. International Atomic Energy Agency (IAEA), Vienna

Edmunds WM, Wright EP (1979) Groundwater recharge and paleoclimate in the Sirte and Kufra Basin. Libya J Hydrol 40:215-235

Epstein S, Mayeda TK (1953) Variations of ${ }^{18} \mathrm{O}$ content of waters from natural sources. Geochem Cosmochim Acta 4:213-224

FAO (1985) Water quality for agriculture. irrigation and drainage paper no 29, Rev 1, Food and Agriculture Organization of the United Nations, Rome

Farnham IM, Stetzenbach KJ, Singh AK, Johannesson KH (2002) Treatment of nondetects in multivariate analysis of groundwater geochemistry data. Chem Intell Lab Syst 60:265-281

Faure G, Mensing TM (2005) Isotopes: principles and applications, 3 rd edn. John Wiley \& Sons, USA

Fontes JC, Yousfi M, Allison GB (1986) Estimation of long-term diffuse groundwater discharge in the northern Sahara using stable isotope profiles in soil water. J Hydro 86:315

Gampson EK, Nartey VK, Golow AA, Akiti TT (2013) Hydrochemical study of water collected at a section of the Lower Volta River (Akuse to Sogakope area). Appl Water Sci, Ghana. doi:10. 1007/s13201-013-0136-8

Gasse F, Fontes JC, Carbonel F, Plaziat JC, Soulie Marsche I, Kaczmarcska I, Dupeuble PA (1987) Biological remains, geochemistry and stable isotope for the reconstruction of environmental and hydrological changes in the Holocene lakes from North Sahara. Palaeo 3(60):1-46

Grande JA, Gonzalez A, Beltran R, Sanchez-Rodas D (1996) Application of factor analysis to the study of contamination in the aquifer system of Ayamonte-Huelva (Spain). Groundwater 34(1):155-161

Güler C, Thyne GD (2004) Hydrologic and geologic factors controlling surface and groundwater chemistry in Indian Wells-Owens Valley area, southeastern California. USA J Hydrol 285:177-198

Helena B, Pardo R, Vega M, Barrado E, Fernandez JM, Fernandez L (2000) Temporal evolution of groundwater composition in an alluvial aquifer (Pissuerga River, Spain) by principal component analysis. Water Resear 34:807-816

Helstrup T, Jørgensen NO, Banoeng-Yakubo B (2007) Investigation of hydrochemical characteristics of groundwater from Cretaceous-Eocene limestone aquifer in southern Ghana and Togo using hierarchical cluster analysis. Hydrogeol 15:977-989

Hernandez MA, Gonzalez N, Levin M (1991) Multivariate analysis of a coastal phreatic aquifer using hydrochemical and isotopic indicators, Buenos Aires, Argentina. In: Proceedings of the International Association on Water Pollution Research and Control's International Seminar on Pollution, Protection and Control of Groundwater, vol 24. Water Science and Technology, pp 139-146

Huizar R, Mendez T, Madrid R (1998) Patterns of groundwater hydrochemistry in Apan-Tochac sub-basin, Mexica. Hydrol Sci 43(5):669-685

Join JL, Coudray J, Longworth K (1997) Using principal components analysis and $\mathrm{Na} / \mathrm{Cl}$ ratios to trace groundwater circulation in a volcanic island: the example of Reunion. J Hydrol 190(1-2):1-18

Kaiser HF (1960) The application of electronic computers to factor analysis. Educ Psychol Measur 20:141-151 
Kelly VP (1951) Alkali Soils: their formation properties and reclamations. Reinhold, New York

Kortatsi BK, Sekpey NK (1994) Chemical and isotopic techniques for the origin of groundwater in the crystalline basement complex of the Upper Region of Ghana. Regional trends in Geology in African Geology. In: Proceedings of the 9th International Geological Conference, Accra, Geological Society of Africa, 2nd-7th Nov 1992

Kuells C, Adar EM, Udluft P (2000) Resolving patterns of ground water flow by inverse hydrochemical modeling in semi-arid Kalahari basin. Tracers Model Hydrogeol 262:447-451

Liedholz T, Schafmeister MT (1998) Mapping of hydrochemical groundwater regimes by means of multivariate statistical analyses. In: Buccianti A, Nardi G, Potenza R (ed) Proceedings of the Fourth Annual Conference of the International Association for Mathematical Geology, October 5-9, Ischia, Italy, International Association for Mathematical Geology, Kingston, pp 298-303

Locsey KL, Cox ME (2003) Statistical and hydrochemical methods to compare basalt- and basement rock-hosted groundwaters: atheron Tablelands, northeastern Australia. Env Geol 43(6):698-713

Lower Volta Environmental Impact Studies, LVEIS (1999) Report for second Phase. Volta Basin Research Project Consultancy Report N/99 to Volta River Authority (VRA) p 42

Massart DL Kaufman L (1983) The interpretation of analytical chemical data by the use of cluster analysis. Wiley, New York

Meng SX, Maynard JB (2001) Use of statistical analysis to formulate conceptual models of geochemical behavior: water chemical data from Butucatu aquifer in Sao Paulo State, Brazil. J Hydrol 250:78-97

Ministry of Local Government and Rural Development, Ghana (2010)

Moniod F, Pouyaud B, Sechet P (1977) Le Bassin du Fleuve Volta. Monogaphies Hydrologiques Orstom, no 5, Paris

Morrison G, Fatoki OS, Ekberg A (2001) Assessment of the impact of point source pollution from Keiskammahoek sewage treatment plant on the Keiskamma River- $\mathrm{pH}$, electrical conductivity, oxygen-demanding substances (COD) and nutrients. Water SA $27: 475-480$

Opoku-Ankomah Y (1998) Volta basin system surface water resources in management study, information building block Part II, vol 2. Ministry of Works and Housing, Accra

Pelig-Ba KB, Kortatsi BK, Edmunds WM (1990) Application of isotope techniques in Groundwater studies in the Upper Regions of Ghana. In: Proceedings of Paper presented at the Regional Seminar on Isotope in Hydrology for Developing Countries in Africa from 15th to 19th Oct 1990 in Vienna, Austria

Pereira HG, Renca S, Sataiva J (2003) A case study on geochemical anomaly identification through principal component analysis supplementary projection. Appl Geochem 18:37-44

Preda M, Cox ME (2000) Sediment-water interaction, acidity and other water quality parameters in a subtropical setting, Pimpama River, southeast Queensland. Environ Geol 39(3-4):319-329

Razack M, Dazy J (1990) Hydrochemical characterization of groundwater mixing in sedimentary and metamorphic reservoirs with combined use of Piper's principle and factor analysis. J Hydrol 114(3-4):371-393

Richards LA (1954) Diagnosis and improvement of saline and alkaline soils [M]. US Department of Agriculture Hand Book, p 60

Salifu M, Yidana SM, Osae S, Armah YS (2013) The Influence of the Unsaturated Zone on the High Fluoride Contents in Groundwater in the Middle Voltaian Aquifers-the Gushegu District, Northern Region of Ghana. J Hydrogeol Hydrol Eng 2:2

Sanchez-Martos F, Jimenez-Espinosa R, Pulido-Bosch A (2001) Mapping groundwater quality variables using PCA and geostatistics: a case study of Bajo Andarax, southeastern Spain. Hydrol Sci 46(2):227-242
Saravanakumar AM, Rajkumar J, Serebiah S, Thivakaran GA (2008) Seasonal variations in physico-chemical characteristics of water, sediment and soil texture in arid zone mangroves of KachchhGujarat. J Environ Biol 29:725-732

Seyhan E, van-de Griend AA, Engelen GB (1985) Multi multivariate analysis and interpretation of the hydrochemistry of dolomitic reef aquifer, northern Italy. Water Res Res 21(7):1010-1024

Simeonov V, Stratis JA, Samara C, Zachariadis G, Voutsa D, Anthemidis A (2003) Assessment of the surface water quality in Northern Greece. Water Res 37:4119-4124

Singh KP, Malik A, Sinha S (2005) Water quality assessment and apportionment of pollution sources of Gomti river (India) using multivariate statistical techniques: a case study. Anal Chim Acta 538:355-374

Sonntag C, Klitsch E, Lohnert EP, El Shzly EM, Munnich KO, Junghans C, Thornweithe V, Weistroffer K, Swalem FM (1979) Palaeoclimatic information from deuterium and oxygen-18 in carbon-14-dated north Saharan groundwaters: Groundwater formation in the past, Isotope Hydrology. In: Proceedings of Symposium Neuherberg 1978, IAEA, Vienna, p 569

Stroomberg GJ, Freriks IL, Smedes F, Cofino WP (eds) (1995) In quality assurance in environmental monitoring. P. Quevauviller $\mathrm{VCH}$, Weinheim

Suk H, Lee KK (1999) Characterization of hydrochemical system through multivariate analysis: clustering into groundwater zones. Groundwater 37(3):358-366

Szabolcs I, Darab C (1964) The influence of irrigation water of high sodium carbonate content of soils. In: Proceedings of 8 th International Congress of Isss, Trans II, pp 803-812

The US Salinity Laboratory of the Department of Agriculture, US Salinity Laboratory Staff (1954)

Todd DK (1959) Groundwater hydrology [M]. Wiley, New York, p 535

Todd DK (1980) Groundwater hydrology [M], 2nd edn. Wiley, New York, p 535

Usunoff EJ, Guzman-Guzman A (1989) Multivariate analysis in hydrochemistry: an example of the use of factor and correspondence analyses. Groundwater 27(1):27-34

Vega M, Pardo R, Barrado E, Deban L (1998) Assessment of seasonal and polluting effects on the quality of river water by exploratory data analysis. Water Res 32:3581-3592

Wang Y, Ma T, Luo Z (2001) Geostatistical and geochemical analysis of surface water leakage into groundwater on regional scale: a case study in the Liulin karst system, northwestern China. J Hydrol 246(1-4):223-234

Ward AD, Elliot WJ (eds) (1995) Environmental hydrology. CRC Press, Boca Raton, $\mathrm{p} 1$

WHO (2004) Guidelines for drinking-water quality, 3rd edn. WHO, Geneva, Switzerland

Whyte SA (1981) A Case for the salvaging of the clam industry of the Lower Volta Basin. Technical Report 2B, Volta Basin Research Project. University of Ghana, Legon, p 7

Willet P (1987) Similarity and Clustering in Chemical Information Systems. Research Studies Press, Wiley, New York

Miyoshi T, Nagayo N (2006) A study of the effectiveness and problems of JICA's technical cooperation from a capacity development perspective: Case study of support for the advancement of Ghana's irrigated agriculture. In: Proceedings of case study report on capacity development. Tokyo, Japan Institute for International Cooperation, Japan International Cooperation Agency

Yidana SM, Ophori D, Banoeng-Yakubo B (2008) A multivariate statistical analysis of surface water chemistry-the Ankobra basin, Ghana. J Environ Manag 86:80-87

Zentrum fur Entwicklungsforschung (ZEF) (2008) Center for Development Research. Uninersity of Bonn, Germany 